\title{
How Well Does the New Keynesian Sticky-Price Model Fit the Data?
}

\author{
John M. Roberts \\ Board of Governors of the Federal Reserve System \\ Stop 76 \\ Washington D.C. 20551
}

February 2001

\begin{abstract}
The New Keynesian sticky-price model has become increasingly popular for monetary-policy analysis. However, there have been conflicting results on the empirical performance of the model. In this paper, I attempt to reconcile these conflicting claims by examining various specifications of the model within the context of a single framework. I find that the New Keynesian model does not fit the U.S. data well; in particular, the model requires additional lags of inflation not implied by the model under rational expectations. These additional lags have the interpretation that some fraction of the population uses a simple univariate rule for forecasting inflation.
\end{abstract}

The views expressed in this paper are those of the author and should not be construed as those of any member of the Board of Governors of the Federal Reserve system or any other member of its staff. Earlier versions of this paper were presented in seminars and workshops at the January 2000 Econometric Society meetings in Boston; the European Central Bank; and the Federal Reserve Board. I am grateful to seminar participants for helpful comments. 
The New Keynesian sticky-price model has received increasing attention in recent years. For example, King and Wolman (1999), Levin, Wieland, and Williams (1999), and Rotemberg and Woodford $(1997,1999)$ incorporate New Keynesian sticky-price assumptions in models that they use for policy evaluation. At the same time, however, questions have arisen about the empirical validity of the model. Fuhrer and Moore (1995) have argued that the standard New Keynesian model with sticky prices and rational expectations does not fit U.S. post-war data. Fuhrer (1997b) and Roberts (1998) have shown that modifying the model so that the it includes lags of inflation not predicted by the standard model with rational expectations allows it to fit the data well.

These additional lags have been justified by various arguments. Roberts $(1997,1998)$ argues that the additional inflation lags can be interpreted as meaning that some agents use simple autoregressive rules of thumb to forecast inflation. By contrast, Brayton, et al. (1997) and Fuhrer and Moore (1995) argue that the additional lags reflect characteristics of the structure of the economy.

While Fuhrer (1997b) and Roberts (1998) claim empirical support for the role for additional lags in the New Keynesian Phillips curve, there is not, to date, a consensus concerning the empirical performance of the New Keynesian sticky-price model under rational expectations. In particular, Rotemberg and Woodford $(1997,1999)$ claim empirical support for the original New Keynesian sticky-price model under rational expectations. They argue that allowing for a serially correlated error term permits the model to fit U.S. data well over the post-1979 period with purely rational expectations.

These competing views matter, because policy implications differ markedly depending on whether the fully or partially rational versions of the New Keynesian model are adopted. Rotemberg and Woodford (1997) show that in their model with fully rational expectations, an optimized central-bank reaction function ought to have a very large coefficient on lagged interest 
rates and a small coefficient on deviations of output from its trend level. By contrast, Levin, Wieland, and Williams (1999) show that in the Fuhrer-Moore (1995) model, which can be interpreted as putting a weight of one-half on lagged inflation and one-half on forward-looking expectations, the optimal coefficient on lagged interest rates should be close to one and the optimal rule will imply a large coefficient on output deviations. Furthermore, as discussed in Roberts (1998), an explicit policy of disinflation has very different implications in the two models, with output and employment costs of disinflation considerably smaller when expectations are fully rational.

More recently, Sbordone (1998) and Gali and Gertler (1999) have argued that if price dynamics are estimated conditional on labor costs, the additional lags of inflation that are not predicted by the New Keynesian model under rational expectations are no longer needed. Earlier work by Roberts, Stockton, and Struckmeyer (1994) had obtained a similar result. Of course, making the model conditional on labor costs rather than on aggregate economic activity in effect splits the aggregate Phillips curve into two pieces, one of which explains prices conditional on labor costs and the other of which explains labor costs; Sbordone and Gali and Gertler examine only the first of these pieces. Hence, the finding that the model conditional on labor costs does not require additional lags of inflation may suggest that the failure of the New Keynesian model stems from the behavior of labor costs and not from the adjustment of prices conditional on labor costs. However, as I will discuss shortly, the results of this paper cast some doubt on the interpretation that Sbordone (1998) and Gali and Gertler (1999) give to their findings.

The question of which model ought to be used for policy analysis is ultimately empirical. To date, the question remains open, because the competing models have been examined separately, over different time periods, and with different econometric techniques. For example, Fuhrer (1997a, b) uses full information maximum likelihood techniques over a long post-war sample, while Rotemberg and Woodford $(1997,1999)$ combine limited-information techniques with a moment-matching approach, focusing on the post-1979 period. The purpose of the 
present paper is to attempt to resolve these tensions by using a common estimation framework to examine the competing models. To further this goal, I include extensive sensitivity analysis, examining alternative measures of inflation and economic activity.

To summarize, the results generally favor models that include lags of inflation. Thus, the New Keynesian model with purely rational expectations that has been favored by Rotemberg and Woodford is rejected in favor of versions that allow for some deviation from perfect rationality, as in Roberts $(1997,1998)$. I also find that explicitly allowing for serial correlation in the error term of the standard model does not improve its ability to fit the data.

While I find that the New Keynesian model apparently needs to be supplemented by lagged inflation to fit U.S. data, in most cases, the required weight on lagged inflation is moderate. In particular, I find that in most of the specifications, the weight on lagged inflation was significantly less than one. This result is in contrast to Fuhrer (1997b), who found a point estimate of 0.8 , which was not significantly different from one.

The results turn out to be sensitive to accounting for potential breaks in monetary policy regime. In particular, I find that once I take into account the possibility that there may have been a break in monetary policy around 1979, as has been argued by, for example, Fuhrer (1997a); Rotemberg and Woodford (1997); and Clarida, Gali, and Gertler (1998), there is a marked increase in the precision of the estimates of the key parameters of the structural Phillips curve. When I allow for this break, I find that the weight on lagged inflation is in the range of 0.5 to 0.7, with limited sensitivity to specification choice.

On the question of the New Keynesian model conditional on labor costs, I find that the results emphasized by Sbordone (1998) and Gali and Gertler (1999) are sensitive to the specification of labor costs. In particular, I find that their results are dependent on the use of average labor productivity as a measure of the marginal product of labor. I argue that because average labor productivity is itself a strongly procyclical variable, the results of Sbordone and Gali and Gertler can be given an interpretation as a traditional aggregate Phillips curve. I also 
argue that this interpretation calls into question their conclusion that the degree of nonrationality is low.

The outline of the remainder of the paper is as follows:

- $\quad$ Section 1 reviews the New Keynesian model of sluggish price adjustment.

- $\quad$ Section 2 discusses the empirical framework that will be used in this paper.

- $\quad$ Section 3 presents estimates of the version of the model with an extra lag of inflation.

- $\quad$ Section 4 presents estimates of the model assuming serially correlated errors.

- $\quad$ Section 5 presents estimates of the variant of the model conditional on labor costs.

- $\quad$ Section 6 presents conclusions.

\section{The New Keynesian model}

\section{1 - The partial-adjustment principle}

In New Keynesian models, prices are "sticky" — that is, they do not adjust immediately to their long-run target level. A common modeling strategy that captures such sluggish adjustment is the quadratic adjustment cost (QAC) model. The QAC model was first developed as a model of investment (see, for example, Lucas, 1967), but was extended to the analysis of sticky prices by Rotemberg (1982). In the quadratic adjustment costs model, costs of adjusting prices are assumed to be increasing in the square of the change in prices. Firms weigh the costs of changing their prices against the costs of being away from the price they would charge in the absence of costly price adjustment. Solving the firm's dynamic maximization problem implies the following first-order condition (see Rotemberg, 1982, or Roberts, 1995, for details):

$$
\Delta p_{t}-E_{t} \Delta p_{t+1}=\left[(1-\theta)^{2} / \theta\right]\left(c_{t}-p_{t}\right)+\epsilon_{t},
$$

where $\Delta p_{t}$ is inflation, $E_{t} \Delta p_{t+1}$ is the expectation in period t of inflation in period $t+1, c$ is the $\log$ of marginal cost, $\epsilon$ is a stochastic error term, and $\theta$ is the rate of partial adjustment of prices. Calvo (1983) has derived an identical reduced-form model assuming a particular kind of staggered price contracts; see Rotemberg (1987) or Roberts (1995) for a discussion of the relationship between these models. 


\section{2 - Deriving an aggregate Phillips curve}

Marginal cost relative to overall prices - the $c_{t}-p_{t}$ term from the partial-adjustment model - will be affected both by the firm's marginal cost schedule and by labor-supply decisions. These phenomena will tend to make $c_{t}-p_{t}$ be rising in aggregate activity, which can be captured as:

$$
\left(c_{t}-p_{t}\right)=\beta y_{t},
$$

where $y$ is the deviation of aggregate output from its trend level and $\beta$ summarizes the slopes of labor supply and marginal cost.

Under this specification, the model becomes:

$$
\Delta p_{t}-E_{t} \Delta p_{t+1}=\left[\beta(1-\theta)^{2} / \theta\right] y_{t}+\epsilon_{t},
$$

which, as noted in Roberts (1995), can be interpreted as an expectations-augmented Phillips curve. ${ }^{1}$

\section{3 - Empirical problems with the model and proposed solutions}

Starting with Fuhrer and Moore (1995), it has been pointed out that the New Keynesian Phillips curve under the assumption of rational expectations has difficulty fitting U.S. data. However, as shown by Fuhrer and Moore (1995) and Fuhrer (1997a, 1997b), if additional lags of inflation are added to the model, the fit of the model is improved considerably.

Various arguments have been made as to the role of lagged inflation. Brayton, et al., (1997) provide a structural interpretation. They extend the quadratic adjustment cost model to allow for higher-order adjustment cost, which will imply that lagged inflation will appear in the reduced form of the price-adjustment equation. Fuhrer and Moore (1995) make an alternative structural argument, relying on a model originally developed by Buiter and Jewitt (1981) which relies on the interaction between nominal rigidity and underlying real-wage behavior that

\footnotetext{
${ }^{1}$ Notice that the Phillips curve slope will be sensitive to the frequency of the data used to estimate the model. In particular, it is easy to show that in annual data, the slope will be at least sixteen times larger than when the model is estimated with quarterly data.
} 
associates real-wage changes with the level of economic activity, rather than real-wage levels, as was the case, for example, in equation 2.

While the preceding arguments rely on microeconomic structure, I have argued in Roberts $(1997,1998)$ that the source of these additional lags may be some deviation of inflation expectations from full rationality. In particular, suppose that inflation expectations are a weighted average of rational expectations and a simple univariate forecast of inflation, perhaps because some fraction of the population uses a univariate rule for forecasting inflation, so that:

$$
E_{t} \Delta p_{t+1}=(1-\omega) M_{t} \Delta p_{t+1}+\omega \rho \Delta p_{t-1},
$$

where the operator " $M_{t}$ " is introduced to distinguish the rational, or "mathematical," expectation from other possible expectation-formation mechanisms. The parameter $\omega$ can be interpreted as the fraction of the population that does not have rational expectations and $\rho$ is the coefficient of a univariate regression of inflation on lagged inflation.

With this assumption about expectations, the model becomes:

$$
\Delta p_{t}=\left[\beta(1-\theta)^{2} / \theta\right] y_{t}+(1-\omega) M_{t} \Delta p_{t+1}+\omega \rho \Delta p_{t-1}+\epsilon_{t} .
$$

In this framework, if inflation has a unit root, then $\rho$ will be one. With this assumption, the model becomes:

$$
\Delta p_{t}=\left[\beta(1-\theta)^{2} / \theta\right] y_{t}+(1-\omega) M_{t} \Delta p_{t+1}+\omega \Delta p_{t-1}+\epsilon_{t} .
$$

An equation of this form that has been estimated, for example, by Fuhrer (1997b) and Chadha, Masson, and Meredith (1992).

It is worth noting that the model derived under less-than-rational expectations and the models based on alternative microfoundations can be shown to be observationally equivalent in many contexts. For example, as discussed in Roberts (1997), Fuhrer and Moore's can be shown to be identical to the model of imperfectly rational expectations in equation 4 , with $\omega=1 / 2$.

While the structural models and the models based on imperfectly rational expectations can be shown to have the same reduced form, I argue in Roberts (1997) that surveys of inflation expectations can be used to distinguish between the structural and expectational sources of lagged inflation. Briefly, I find that if surveys are assumed to capture inflation expectations 
accurately, then there is no need for additional lags of inflation. Hence, if surveys accurately reflect inflation expectations, this result would appear to imply that it is imperfectly rational expectations and not the underlying structure of the economy that accounts for the presence of lagged inflation in empirical estimates of the New Keynesian model.

This argument would be strengethened if it were the case that inflation expectations as captured by the surveys were well represented as being a weighted average of forward-looking and backward-looking expectations. In Roberts (1998), I show that this is indeed the case. In particular, I estimate equation 3 directly, using survey measures of inflation expectations as a proxy for actual expectations. I find $\omega=0.4$, which has the interpretation that 40 percent of the population uses a simple univariate rule for forecasting inflation while the remaining 60 percent has rational expectations.

While these findings are of interest, they rely on survey estimates of inflation expectations, which can be viewed with suspicion, as survey respondents have little incentive to take them seriously. The findings based on the survey results would be buttressed if direct estimation of equation 4 yielded similar results - namely, that $\omega$ is 0.4 . Fuhrer (1997b) has a model like equation 4 and finds that a point estimate for $\omega$ of 0.8 and further finds that it is not statistically significant different from one. ${ }^{2}$ Resolving the discrepancies among these estimates is one of the objectives of the present paper.

\section{4 - Adding a serially correlated error term}

Adding a lagged variable to a model can often be a way of compensating for an omitted serially correlated error term. This insight motivates an alternative solution to the problem, suggested by Rotemberg and Woodford (1997). Thus, suppose that the true model is:

$$
\begin{aligned}
& \Delta p_{t}-M_{t} \Delta p_{t+1}=\left[\beta(1-\theta)^{2} / \theta\right] y_{t}+u_{t} \\
& \text { and } u_{t}=\phi u_{t-1}+\eta_{t:} .
\end{aligned}
$$

${ }^{2}$ Chadha, Masson, and Meredith (1992) have also estimated equation 4 directly. They found $\omega=0.5$. However, their estimates were based on annual data from several countries taken together and so are less comparable to the estimates of the present paper, which, like Fuhrer (1997b), use U.S. quarterly data. 
This model can be rewritten as:

$$
\Delta p_{t}=\left[\beta(1-\theta)^{2} / \theta\right]\left(y_{t}-\phi y_{t-1}\right)+\phi \Delta p_{t-1}+M_{t} \Delta p_{t+1}-\phi M_{t-1} \Delta p_{t}+\eta_{t}
$$

While not identical to the model with less-than-rational expectations, this model bears some resemblance to it, notably in the presence of lagged inflation. Hence, it is possible that results suggesting some weight on lagged inflation may in fact be picking up a serially correlated error. In particular, Rotemberg and Woodford $(1997,1999)$ have suggested that the New Keynesian model may well include a serially correlated error term. Their argument is that simple detrending procedures may miss some of the variation in "trend" output. While they do not propose an explicit specification of the serially correlated error term, the argument here is intended to capture the spirit of their suggestion.

\section{5 - The model with labor costs}

An alternative approach to the New Keynesian partial-adjustment model has been to assume that marginal cost is well-represented by labor costs. This approach has been used by Roberts (1992) and Roberts, Stockton, and Struckmeyer (1994), and, more recently, by Sbordone (1998) and Gali and Gertler (1999). Thus, it is assumed that:

$$
c_{t}=w_{t}-\log \left(M P L_{t}\right),
$$

where $w$ is the log of the wage and MPL is the marginal product of labor. In Roberts (1992) and Roberts, Stockton, and Struckmeyer (1994), it was assumed that:

$$
\log \left(M P L_{t}\right)=\gamma y_{t}+a_{t}
$$

where $a_{t}$ is a stochastic process reflecting movements in the marginal product of labor that are unrelated to aggregate economic activity. By contrast, Sbordone (1998) and Gali and Gertler (1999) assume that the marginal product of labor is proportional to the average product of labor:

$$
\log \left(M P L_{t}\right)=y_{t}-h_{t},
$$

where $\mathrm{h}$ is the log of aggregate hours worked. Under this assumption, the partial adjustment model becomes:

$$
\Delta p_{t}-E_{t} \Delta p_{t+1}=\left[(1-\theta)^{2} / \theta\right] s_{t}+\epsilon_{t},
$$


where $s=w+h-(y+p)$, or the log of labor's share. Alternatively, under the assumption of Cobb-Douglas production technology, $s$ can be thought of as (minus) the log of the markup of price over unit labor cost (up to an additive constant), where unit labor cost is defined to be the wage divided by average labor productivity.

Each of these approaches to modeling the marginal product of labor has potential difficulties. Modeling the marginal product of labor to include an important stochastic trend requires differencing the price adjustment equation; if the data contain measurement error, such differencing will reduce the signal-to-noise ratio. On the other hand, assuming that the marginal product of labor is proportional to the average product of labor runs into the well-known procyclicality of average labor productivity, which some analysts have interpreted as meaning that average labor productivity deviates from marginal productivity, perhaps because of socalled "labor hoarding."

It is worth emphasizing that there is no tension between this model and the Phillips curve. The Phillips curve can be thought of a stylized model that summarizes the effects of economic activity on all dimensions of marginal cost. The model conditional on labor costs is looking at a narrower set of phenomena than the Phillips curve, and is implicitly leaving any influence of aggregate economic activity on labor costs to be explained by another model. The Phillips curve can thus be thought of as the reduced form of the model conditional on labor costs and an additional model linking labor costs and aggregate economic activity.

In empirical implementation of the model with partial adjustment toward a measure of labor costs, Roberts, Stockton, and Struckmeyer (1994), Sbordone (1998), and Gali and Gertler (1999) have found that the model appears to perform well without the need to add an additional lag of inflation. An interpretation of this result is that the problems with the reduced-form Phillips curve must stem from the properties of labor costs - for example, because of less-thanrational expectations in the formation of wages. However, because of the problems with the measures of the marginal product of labor used in each of these studies, this conclusion may be premature. 


\section{The empirical framework}

\section{1 - Deriving the specification for estimation}

In this section, I derive the versions of the models I will use in the empirical work. I first consider the model in which some agents are assumed to use simple univariate forecasting rules:

$$
\Delta p_{t}=\gamma y_{t}+(1-\omega) M_{t} \Delta p_{t+1}+\omega \rho \Delta p_{t-1}+\epsilon_{t} .
$$

where $\gamma=\left[\beta(1-\theta)^{2} / \theta\right]$, the Phillips curve slope.

In my estimation, I make the assumption that $\rho=1$. Standard tests suggest that over the period I examine, the hypothesis that U.S. inflation had a unit root cannot be rejected. ${ }^{3}$ Also, assuming that $\rho=1$ is consistent with earlier work in this area, such as Fuhrer (1997b). With this assumption, there is a restriction imposed across the coefficients on lagged and expected inflation. To impose this restriction, I rewrite the model as:

$$
\Delta p_{t}-M_{t} \Delta p_{t+1}=\gamma y_{t}+\omega\left(\Delta p_{t-1}-M_{t} \Delta p_{t+1}\right)+\epsilon_{t} .
$$

Note that rewriting the model in this way also has the effect of making statistical inference robust to the presence of a unit root in inflation.

I focus on instrumental variables techniques to estimate the model. As is well-known, full-information techniques, as were used by Fuhrer (1997a, b), have greater econometric efficiency when the correct specification of the model is known. On the other hand, limited information techniques are robust to incorrect model specifications — and, more prosaically, to skepticism about modeling assumptions. Moreover, because of their lower computational costs, limited information techniques more readily allow repetitive sensitivity analysis, a strategy I adopt here.

In implementing my limited information approach, I replace the mathematical expectation of inflation with its actual outcome. Provided that the instruments are limited to

\footnotetext{
${ }^{3}$ In particular, I examine the U.S. CPI and the U.S. GDP chain price index over the period 1957 to 1997. For each inflation series, I conducted an augmented Dickey-Fuller test, including four lagged changes in the inflation rate and a constant term in each regression. For the CPI, the $t$-ratio on the lagged level of inflation is 2.2; for the GDP chain price index, the $t$-ratio is 1.9. In both cases, the test statistics are far from the 5 percent confidence level of the test, for which the $t$-ratio is 3.2 .
} 
those that would have been part of the information set of agents at the time expectations were formed, this substitution will yield estimates consistent under the rational expectations hypothesis. With this modification, the equation becomes:

$$
\Delta p_{t}-\Delta p_{t+1}=\gamma y_{t}+\omega\left(\Delta p_{t-1}-\Delta p_{t+1}\right)+\epsilon_{t}^{\prime},
$$

where $\epsilon_{t}^{\prime}=\epsilon_{t}+(1-\omega)\left(M_{t} \Delta p_{t+1}-\Delta p_{t+1}\right)$.

Fuhrer (1997b) made a further modification of the model. He replaced the single lead and lag of inflation with a three-quarter average of inflation. One justification for such a modification is that some prices are set for a year at a time, implying concern for inflation several quarters ahead. With this modification, the model becomes:

$$
\begin{aligned}
& \Delta p_{t}-\left(\Delta p_{t+1}+\Delta p_{t+2}+\Delta p_{t+3}\right) / 3= \\
& \quad \gamma y_{t}+\omega\left[\left(\Delta p_{t-1}+\Delta p_{t-2}+\Delta p_{t-3}\right)-\left(\Delta p_{t+1}+\Delta p_{t+2}+\Delta p_{t+3}\right)\right] / 3+\epsilon_{t}{ }_{t} .
\end{aligned}
$$

I next consider the model with a serially correlated structural error term. Again, I begin with instrumental variables estimation of the model, replacing expectations with realizations:

$$
\Delta p_{t}=[\gamma /(1+\phi)]\left(y_{t}-\phi y_{t-1}\right)+\left(\phi \Delta p_{t-1}+\Delta p_{t+1}\right) /(1+\phi)+\eta_{t}^{\prime}
$$

where $\eta$ ' includes expectational errors. Rearranging this model will not allow a single parameter to capture information about $\phi$. Still, rearranging does permit a more direct comparison with the less-than-perfectly rational model:

$$
\Delta p_{t}-\Delta p_{t+1}=[\gamma /(1+\phi)]\left(y_{t}-\phi y_{t-1}\right)+[\phi /(1+\phi)]\left(\Delta p_{t-1}-\Delta p_{t+1}\right)+\eta_{t}^{\prime}
$$

Notice that only the presence of lagged output distinguishes this specification from the model with imperfectly rational expectations.

Finally, I also rearrange the model that uses labor costs, in a manner parallel to the way that I rearranged the model that uses a measure of aggregate economic activity. I also consider the possibility of three leads and lags of inflation in this model.

\section{2 - Data}

I examine a variety of measures of economy activity and of inflation. In addition to providing a perspective on the sensitivity of the results, using a range of measures facilitates comparison with other studies. For economic activity, I consider detrended GDP; manufacturing 
capacity utilization; and the unemployment rate. Detrended output has been used in a number of other studies, notably Fuhrer and Moore (1995) and Fuhrer (1997a, b). It is an obvious candidate for capturing aggregate cyclical variation. I detrend (the log of) GDP using the Hodrick-Prescott filter. ${ }^{4}$ Manufacturing capacity utilization is an alternative measure of economic activity. Although it only measures activity in a narrow segment of the economy, capacity utilization is highly cyclical and, unlike GDP, it is clearly stationary, so issues of detrending are not important. The unemployment rate is also an important cyclical indicator. Unemployment has the further advantage that, except for seasonal factors, it is not revised, so estimates using it are robust to the criticism — especially pertinent for models assuming rational expectations - that agents did not have access to the data used in the estimation at the time decisions were made.

For inflation, I use the CPI and the GDP chain-type price index. The CPI is a broad measure of consumer prices. Like the unemployment rate, it has the advantage that it is not revised. The GDP chain price index is a broader measure than the CPI, and is the broadest available measure of product prices. However, that greater coverage comes at a cost: Many of the prices underlying the GDP price index are imputed. By contrast, an advantage of the CPI is that it is based entirely on market prices.

In my analysis of the model conditional on labor costs, I will begin with labor's share in the nonfarm business sector (in logs, $w-p-[y-h]$ ) as the measure of labor cost. Because of the problems with average labor productivity as a proxy for marginal productivity mentioned above, I will also consider a measure that replaces $y$ - $h$ with an estimate of the trend level of output per hour. As with GDP, I use the Hodrick-Prescott filter to detrend output per hour.

\section{3 - Instruments}

As noted above, the model requires instrumental variables estimation because of the use of actual future inflation as a proxy for the expectation; by using instrumental variables, I

\footnotetext{
${ }^{4}$ I use a smoothness parameter of 16,000 rather than the recommended value of 1,600 because the smaller value leads to a "trend" that is clearly procyclical.
} 
effectively ensure that the projection of future inflation on the instruments enters the model. The use of instrumental variables also helps protect against the possibility that the error term in the equation will be correlated with either the economic activity variable or with the difference between lagged and future inflation. And instrumental variables can be useful in protecting against biases stemming from measurement error in the data.

Lagged dependent variables are often used as instruments in macroeconomic models such as this one; lagged economic activity and inflation are obvious candidates. While lagged economic activity will be a principal instrument, I will be more circumspect in my use of lagged inflation. One reason is that, because it is a differenced variable, inflation may be more subject to measurement error. Furthermore, differencing may lead to measurement error with serial correlation. Problems related to measurement error in inflation may be particularly marked for the GDP price index because it incorporates imputed prices in many areas.

Another variable that is useful for predicting economic activity is the short-term interest rate. Short-term interest rates may also be helpful in bringing to bear information about inflation expectations that is not affected by possible measurement problems in the actual inflation data. As a consequence, I will also consider the change in the federal funds rate as an instrument.

The use of future inflation as a proxy for expectations dictates that, in the imperfect rationality model, instruments must be dated period $t$ and earlier and that, in the model with serially correlated errors, the instruments must be dated period $t$ - 1 or earlier. If we also take into account publication lags, so that agents forming their expectations in period $t$ only have information from period $t$ - 1 , then instruments for the imperfect rationality model must be dated period $t-1$ and earlier and for the model with serially correlated errors, they must be dated period $t-2$ and earlier. Given the publication schedules of the major statistical agencies, a one-period publication lag seems reasonable in quarterly data.

A common question in instrumental variables estimation is the number of instruments to use. Generally speaking, using more lags will improve the ability of the instruments to capture movements in the variable of interest. But this benefit must be weighed against the danger of 
using too many instruments in a finite sample. To illustrate this risk, consider the case of estimation of the coefficient on a single right-hand-side variable, where we use the same number of instruments as observations. In this case, the instrumental variables estimate will be identical to the OLS estimate, because the first-stage regression will have fit the variable exactly. While this case is obviously degenerate, it illustrates that, at some point, adding instruments in a finite sample runs the risk of overfitting.

In the present case, I use four lags of each instrument. My main motivation for this choice comes from the VAR literature, in which four lags appear to allow these models to capture the economy's dynamics well. The four main instrument sets I will consider are:

1. Four lags of the economic activity variable;

2. Four lags of the activity variable plus four lags of the change in the fed funds rate;

3. Set 2 plus four lags of the change in inflation;

4. Four lags of activity plus four lags of the change in inflation.

The first two sets of instruments will receive more weight than the latter two because, as mentioned above, there is the risk that lagged inflation may not be a valid instrument. When I discuss the model conditional on labor costs, I will also consider lagged labor-cost variables as instruments.

To allow for the possibility of serially correlated residual error terms, I use a generalized method of moments estimation technique, using the Newey-West weighting matrix and allowing for up to eight-quarter serial correlation.

\section{Estimates of the model with less-than-perfect rationality}

\section{1 - Base results, 1957 to 1997}

Tables 1 to 4 show estimates of the less-than-perfectly rational version of the model for a variety of measures of inflation, economic activity, and instrument sets. Tables 1 and 2 use the basic specification, with a single lead and lag of inflation; tables 3 and 4 show results using three-quarter averages of lead and lag inflation. 
In the results for the specification with only a single lead and lag of inflation, shown in tables 1 and 2, the Phillips curve slope is never statistically significant. However, in all cases in which lagged inflation is not part of the instrument set, it is estimated to have the correct sign. In these cases, the parameter that captures the degree of nonrationality is always statistically different from zero and varies between 0.43 and 1.03 . It is significantly different from one in eight of twelve cases.

When lagged inflation is included in the instrument set, the Phillips curve slope has the wrong sign in ten of twelve cases, and in two of those, it is statistically significant. As pointed out by Gali and Gertler (1999), an interpretation of a structural Phillips curve estimated with the wrong slope is that the model is implicitly estimated with the correct sign, but with a high degree of nonrationality. To understand this interpretation, consider the New Keynesian Phillips curve with rational expectations:

$$
\Delta p_{t}-M_{t} \Delta p_{t+1}=\gamma y_{p}
$$

where, for convenience, we ignore the error term. This equation can be rearranged as:

$$
\Delta p_{t}=\Delta p_{t-1}-\gamma y_{t-1}
$$

Except for the fact that output appears with a lag, this specification is equivalent to assuming that inflation expectations are formed entirely with a univariate forecasting rule; and because economic activity is highly serially correlated, the fact that it appears with a lag doesn't constitute an important difference.

Consistent with this interpretation, the direct estimates of the rationality share are much smaller when the Phillips curve slope has the wrong sign. Indeed, in the estimates in which GDP prices measure inflation, the absolute value of the Phillips curve slope is especially large, and the nonrationality parameter is not significantly different from zero in three of six cases. Of course, as just noted, this result in no way indicates that the degree of nonrationality is small, because the fact that the Phillips curve slope has the wrong sign means the results can be given the opposite interpretation. 
As noted in section 2, there is reason to view the results that include lagged inflation as an instrument with suspicion, because of the risk of serially correlated measurement error, especially in the GDP price index. Hence, we may want to put greater weight on the results that exclude lagged inflation as an instrument. Still, it is hard to claim much support for the Phillips curve model from these results, as the main structural parameter of the model — the Phillips curve slope - is never statistically significant.

Tables 3 and 4 show estimates of specifications that use three leads and lags of inflation instead of one. These estimates are, for the most part, more precise than the results with just one lead and lag: When lagged inflation is not included in the instrument set, the Phillips curve slope is statistically significant at the 5 percent level in six of twelve cases, and at the 10 percent level in a further two cases. The results are also more consistent with the economic logic of the model, as the Phillips curve slope has the correct sign in all but one case. Moreover, in all cases in which the Phillips curve slope has the correct sign, the $J$-test indicates that the instruments are not correlated with the residuals.

When the CPI is the measure of inflation, the results are little affected when lagged inflation is added to the instrument set: The Phillips curve slope continues to have the correct sign, and it is statistically significant in three of six cases. The estimated degree of nonrationality is a bit smaller than in the cases in which lagged inflation is not included in the instrument set, with the largest around 0.6, and in all cases, it is significantly different from one. By contrast, with GDP prices, the results using lagged inflation as an instrument are not successful: When either detrended output or capacity utilization is the measure of economic activity, the Phillips curve slope has the wrong sign. While the slope in the unemployment rate equations has the correct sign, it is much smaller than before, and is no longer statistically significant.

On balance, the results with the CPI appear to be less sensitive to specification than the results with GDP prices. Using the CPI, the Phillips curve slope is statistically significant in five of eight cases, and the results are less sensitive to the exact set of instruments used. In the cases 
where the Phillips curve slope is statistically significant, the degree of nonrationality is estimated to be between 0.60 and 0.75 , and in three of those five cases, it is estimated to be significantly different from one. As in tables 1 and 2, when the Phillips curve slope is smaller, the degree of nonrationality tends to be small, as well. For example, when the unemployment rate is the measure of economic activity, the Phillips curve slope is not significantly different from zero, and the degree of nonrationality is around 0.4 .

The estimates with GDP prices appear to be more sensitive to the choice of instruments, and, in particular, when lagged inflation is added as an instrument, the estimates shift markedly. In general, the estimated degree of nonrationality is higher when GDP prices are used. For example, when the unemployment rate is the measure of economic activity, the estimated degree of nonrationality is about 0.7 to 0.75 , in contrast to 0.4 with CPI inflation. Interestingly, despite the large point estimate for $\omega$, the precision is high enough that we can reject the hypothesis that $\omega$ is equal to one in this case. On the other hand, when capacity utilization is the measure of economic activity, the estimate of the nonrationality parameter actually exceeds one, although not to a statistically significant degree.

One interesting pattern in the results is that when GDP is the measure of inflation and inflation is not among the instruments, the Phillips curve slope is statistically significant at the 10 percent level in the four cases in which detrended GDP was not the measure of economic activity. A possible explanation of this result is that there is correlation between measurement error in real GDP and in GDP prices; because much of real GDP is computed by deflating nominal quantities, this is a distinct possibility. Suggestive in this regard are the results when CPI is the measure of inflation; here, the Phillips curve slope is estimated to be large and statistically significant when detrended GDP is the measure of economic activity.

To explore the possibility that measurement error in economic activity may be biasing the results, in table 5, I use the unemployment rate as an instrument for detrended GDP, and detrended GDP as an instrument for the unemployment rate. In brief, the results are not especially supportive of this approach. In particular, when the GDP price index is the measure 
of inflation, the estimate of the Phillips curve slope when detrended GDP is the measure of economic activity is larger than in table 3, but while the $t$-ratio is also larger, it still falls short of statistical significance. Interestingly, when detrended GDP is used as an instrument for the unemployment rate, the estimated Phillips curve slope is larger than in table 3, but it is no longer statistically significant, apparently because detrended GDP is a sufficiently worse instrument that the precision of the estimate fell. Similarly, when the CPI is the measure of inflation, the coefficient on detrended GDP loses its statistical significance when the unemployment rate is used as an instrument.

A modicum of support for this approach comes when detrended GDP is used as an instrument for the unemployment rate and CPI is the measure of inflation; in this case, the estimated Phillips curve slope is larger than in table 4 and is statistically significant. Given the lack of success for the other specifications, it appears that this method does not in general yield improved estimates.

One robust feature of the results is that the hypothesis of complete rationality is invariably rejected, either because the direct estimate of the nonrationality parameter is significantly greater than zero, or because the Phillips curve slope is estimated to have the wrong sign. There is nonetheless a broad range of estimates of the degree of nonrationality. Despite this broad range of estimates, in most, but not all, cases, the nonrational share is significantly less than one. This result is in contrast to Fuhrer (1997b), who found that he could not reject the hypothesis of complete nonrationality.

\section{2 - An interpretation of the correlation between the slope of the Phillips curve and the} estimated degree of nonrationality

As the preceding results have made clear, there is wide variation in both Phillips-curve slopes and nonrational shares. A pattern in these results is that these coefficients are positively correlated. That is, when the nonrational share is small, the Phillips-curve slope seems to be small, whereas when the nonrational share is large, the Phillips-curve slope is larger. 
As figure 1 indicates, this result is confirmed by plotting likelihood surfaces for an individual estimate - in this case, for the specification in table 3 that uses the GDP price index as the measure of inflation; the unemployment rate as the measure of economic activity; and four lags of the unemployment rate and four lags of the change in the fed funds rate as instruments. The figure shows two constant-likelihood curves, the inner one for the 50 percent confidence level that the two parameters differ from the point estimate and the outer, for the 10 percent confidence level. Each of the curves is elliptical in shape, suggesting a negatively sloped "ridge" in the plot of the constant-likelihood curves of the two coefficients.

The plot suggests that it is difficult to distinguish between, on the one hand, a flat Phillips curve and a high degree of rationality, and, on the other, a low degree of rationality and a more steeply sloped Phillips curve. Nonetheless, it is worth noting that in figure 1, some hypotheses can be ruled out. In particular, even when the Phillips curve is completely flat, the degree of nonrationality is above one-half, suggesting that despite the broad range of estimates, complete rationality is ruled out. At the other extreme, when the Phillips curve is very steep, the corresponding estimate of $\omega$ falls short of complete nonrationality, at least at the 10 percent confidence level.

There is a ready economic interpretation of the trade-off between the slope of the Phillips curve and the degree of nonrationality: As Ball and Romer (1990) have pointed out, a flatter Phillips curve means that a given nominal shock will have a larger effect on real variables. But as I show in Roberts (1998), given the slope of the Phillips curve, a greater degree of nonrationality will imply a larger effect of certain types of monetary shocks on the real economy — in particular, shocks that lead to a permanent reduction in inflation. Indeed, when there is complete rationality, inflation can be reduced virtually without cost. Hence, a flat Phillips curve and a high degree of nonrationality are alternative ways of generating a large effect of monetary shocks on the real economy. ${ }^{5}$

5 This intuition is confirmed in simulation results, in which the Phillips-curve model is supplemented by some simple, reduced-form relationships for output and interest rates. From this model, 


\section{3 - Allowing for shifts in regime}

Fuhrer (1997a) and Rotemberg and Woodford (1997) raise the concern that there was a major shift in the conduct of monetary policy starting at the end of 1979, which may affect the structural stability of estimation. Fuhrer's (1997a) paper provides evidence of such a break, as do Clarida, Gali, and Gertler (1998).

To guard against the possibility of a break, Rotemberg and Woodford limit estimation to the post-1979 sample. By contrast, Fuhrer (1997a) formally takes account of the change in monetary policy. In particular, Fuhrer estimates his model using full information maximum likelihood techniques and introduces different monetary policy rules for different time periods. In the following, I adapt Fuhrer's approach to my limited-information framework. ${ }^{6}$ I do this by introducing an additional set of instruments, which are zero before 1980 and equal to the level of each of the other instruments thereafter. ${ }^{7}$

Table 6 shows results for the 1957 to 1997 period with the additional set of instruments that is zero before 1980 and equal to the existing set of instruments thereafter. To limit repetition, a single instrument set is used — the set that includes four lags of economic activity and four lags of the change in the federal funds rate. With this new set of instruments, the Phillips curve slopes are significant at the 90 percent level in all but one case and at the

a "sacrifice ratio" can be calculated, which captures the output loss associated with a given permanent reduction in inflation. Simulations of this model indicate that there is a constant sacrifice-ratio trade-off between the Phillips curve slope and the nonrational share.

${ }^{6}$ Fuhrer (1997a, b) presents estimates of the model with lagged inflation over the period 1966:Q1 to 1994:Q1. I re-estimated the models over this sample and found that the results were generally similar. As a consequence, I will focus on structural change in the longer sample. Also, Fuhrer (1997a) allowed for a second change in monetary policy, in 1982. I do not do so, for two reasons. First, because I am using a limited-information technique, introducing a second break would have made the number of instruments untenably large. Second, the 1979 change in policy appears to be the more important of the two - for example, it is this change that Rotemberg and Woodford focus on.

${ }^{7}$ Note that the Fuhrer paper that takes account of the shift in monetary policy (1997a) is a different paper than the one that estimates the degree of nonrationality (1997b). In the former paper, the degree of nonrationality is set equal to 0.5 and not estimated. In the event, it turns out that this assumption is not unreasonable. 
95 percent level in six of ten cases. The variation in the nonrationality coefficient is much smaller than before; it now lies in the range of 0.47 to 0.67 . And it is estimated precisely enough to reject equality to either zero or one at the 95 percent confidence level.

These results suggest that taking account of changes in policy regime can have an important effect on estimates of structural Phillips curves. In particular, taking account of the structural break greatly improves the precision of the results, and the finding that the degree of nonrationality is less than one is now less sensitive to specification. Figure 2 illustrates the change in the precision of the estimates. It presents constant-likelihood curves from the same model as in figure 1, but with the instrument set that allows for breaks. To emphasize the increase in precision, the figure is plotted to the same scale as figure 1. In particular, while the likelihood surface continues to contain a ridge, its peak is more pronounced, indicating that the "trade-off" between the Phillips curve slope and the degree of nonrationality is less pertinent.

\section{The New Keynesian model with serially correlated errors}

As noted above, an autoregressive error term may provide an alternative explanation for the presence of lagged inflation in the New Keynesian model. Of course, an autoregressive structural error term has additional implications as well, and if it were the correct model, failure of the preceding model to account for these features would imply that test statistics such as the $J$ test would generate rejections. The fact that they did not should perhaps increase our confidence that the less-than-rational-expectations interpretation is satisfactory. Still, it is possible that low power in small samples could explain the failure of the model to be rejected, and it is worth pursuing the possibility of an autoregressive error term explicitly.

Table 7 shows results for the model with a serially correlated structural error term. The estimates are not successful: The Phillips curve slope has the wrong sign with each of the measures of economic activity, and each of these coefficients is statistically significant. The estimated serial correlation parameter is small and not statistically significant.

Recall from section 3 that one interpretation of an incorrect Phillips curve slope is that there is a high degree of nonrationality. Under this interpretation, the small size of the serial 
correlation parameter may be related to the earlier finding that when the slope coefficient has the wrong sign, the estimated nonrationality parameter was small. In any case, the results can be taken as a repudiation of the notion that adding a serially correlated error term to the model can account for the lag of inflation that appears when the model is estimated without serially correlated errors.

The last three columns of the table indicate that these results are not sensitive to sample: When the sample is limited to 1980:Q1 to 1995:Q2, the period Rotemberg and Woodford (1997) examine, the results are very similar. Other results (not shown) indicate that the results are not sensitive to adding lags of the change in inflation as instruments.

\section{Estimates of the partial adjustment model conditional on labor costs}

As discussed in section 1, the partial adjustment model for prices can also be estimated conditional on labor costs. This approach has been taken by Roberts (1992); Roberts, Stockton, and Struckmeyer (1994); Sbordone (1998); and Gali and Gertler (1999). As noted in section one, the partial-adjustment model conditional on labor costs can be thought of as part of a larger system underlying the reduced-form Phillips curve; in particular, to complete the system, some further model must be specified for labor costs.

I begin by presenting estimates using labor's share as a proxy for the ratio of price to unit labor costs, as in Sbordone (1998) and Gali and Gertler (1999). Tables 8, 9, and 10 present estimates of this model. For continuity with the estimates of the reduced-form Phillips curve, I begin with results that use the same instruments as I used in estimating the reduced-form Phillips curve. To reduce the proliferation of results, I examine only results that combine lagged economic activity with either lagged federal funds rate changes or lagged inflation changes. I also consider instrument sets that add lagged labor's share to the instrument set.

Table 8 shows results using only one lead and one lag of inflation. To limit repetition, I focus on results using GDP prices; results using the CPI were qualitatively similar, although less precise. Labor's share is never significant when the unemployment rate is included as an instrument. However, it is significant at the 10 percent level in three of four specifications with 
detrended GDP in the instrument set and in both cases when capacity utilization and lagged labor's share are in the instrument set. The estimated degree of nonrationality is notably lower than in the reduced-form Phillips curve, especially when lagged inflation is included in the instrument set.

Tables 9 and 10 show results using three leads and lags of inflation instead of just one lead and lag with both the CPI and the GDP price index as measures of inflation. As with the reduced-form Phillips curve, the results are more precise with three leads and lags — in particular, the coefficient on labor's share is more often significant. When lagged labor's share is not included as an instrument, detrended GDP appears to be the best instrument for movements in labor's share. When labor's share is included in the instrument list, the coefficient on labor's share is significant at least at the 10 percent level in ten of the twelve cases in tables 9 and 10. In common with the results in table 8 , the estimated nonrational share is smaller than in the reduced-form Phillips curve, in the range of 0.29 to 0.46 when GDP prices are used and 0.14 to 0.37 with the CPI.

As noted in section 1, it may be worthwhile determining the extent to which the results depend on the use of average labor productivity as a measure of the marginal product of labor. To explore this issue, I split labor's share into two pieces, one that is the deviation of labor productivity from its trend value and the other that recalculates labor's share using trend productivity rather than actual productivity. That is, I rearrange labor's share as:

$$
\begin{aligned}
\log (\text { share })=w-p-(q-h) & =\left[w-p-(q-h)^{*}\right]-\left[(q-h)-(q-h)^{*}\right] \\
& =s^{*}-\left[(q-h)-(q-h)^{*}\right],
\end{aligned}
$$

where $s^{*}=\left[w-p-(q-h)^{*}\right]$, or labor's share computed using trend labor productivity. I then use $s^{*}$ and $\left[(q-h)-(q-h)^{*}\right]$ as separate right-hand-side variables. If labor's share is the appropriate variable to use in the partial-adjustment model, then the two terms will have equal and opposite coefficients.

The top panel of table 11 shows results using lags of economic activity, labor's share, and either the change in the federal funds rate or the change in inflation as instruments. In the 
bottom panel, I add lags of detrended labor productivity as additional instruments. To limit repetition, I consider results using only detrended GDP as an instrument for economic activity; as noted above, detrended output seems to lead to sharper estimates than the other measures of activity.

The results in table 11 are not favorable to the simplest story about labor's share as a good measure of the ratio of labor cost to price. In particular, detrended labor productivity has large coefficients in all specifications, and is statistically significant at the 10 percent level in six of eight cases. By contrast, labor's share computed using trend labor productivity $\left(s^{*}\right)$ is never statistically significant and has the wrong sign in all four specifications in the upper panel. In the lower panel, where detrended labor productivity is added as an instrument, the coefficient on $s^{*}$ has the correct sign but it is always much smaller than the coefficient on detrended labor productivity. The parameter measuring nonrationality of inflation expectations is again on the small side; indeed, in the upper panel, the nonrationality parameter is insignificant in three of four cases.

Taken at face value, the results in table 11 suggest that when labor productivity falls relative to trend, the increase in costs leads to an increase in current inflation relative to expected future inflation. This aspect of the results is as expected for the partial adjustment model conditional on labor costs. However, the model also predicts that other increases in labor costs ought to have similar consequences for inflation, and this aspect of the model is not borne out.

An alternative interpretation of these results is not so sanguine for the notion that the model is capturing the adjustment of prices to labor costs. As noted before, labor productivity is procyclical. As a consequence, it may be standing in as a cyclical variable. Because it is procyclical, a negative coefficient is the opposite of what the theory predicts. Of course, as noted in section 3, a negative sign on a procyclical variable may instead be a symptom of a high degree of nonrationality. Consistent with this interpretation, the coefficient intended to capture nonrationality is small, similar to the pattern in earlier results in which the cyclical variable had the wrong sign. 
To explore this possibility further, in table 12 I show estimates that include both detrended labor productivity and an economic activity variable. If detrended labor productivity is simply capturing cyclical variation, then including one of the traditional business cycle indicators should reduce or eliminate the significance of detrended productivity. As instruments, I include lags of the measure of economic activity, detrended productivity, and either the change in the federal funds rate or the change in inflation. As table 12 indicates, the results are sensitive to the instruments used. If lagged inflation is not among the instruments, the results are not favorable to detrended labor productivity; the traditional economic activity variable is preferred, and the estimated degree of nonrationality is in the 0.6-to-0.7 range. If, however, the change in inflation is included among the instruments, the results are more mixed. But as noted above, lagged inflation is suspect as an instrument, because of the possibility of serially correlated measurement error in inflation.

The results in table 12 suggest that detrended labor productivity — and thus labor's share - may simply be playing the role of a traditional economic activity variable. These results call into question the interpretation of the model conditional on labor's share emphasized by Sbordone (1998) and Gali and Gertler (1999).

\section{Conclusions}

On balance, the evidence presented here suggests that the answer to the title question is, "Not very well." To fit the U.S. data, the New Keynesian sticky-price model with rational expectations needs to be augmented by additional lags of inflation that are not predicted by the model. An attempt to account for the additional lags of inflation by adding serially correlated

errors to the model was not successful. And while a version of the model conditional on labor's share appeared not to require the additional inflation lags, on closer examination, this result appears to be driven by the cyclical behavior of productivity, and thus could be interpreted as consistent with a reduced-form Phillips curve with a very large coefficient on lagged inflation.

The results of section 3 suggest that, in the model conditional on economic activity, there is a weight of about 60 percent on lagged inflation. Under one interpretation, this result would 
imply that 60 percent of the population uses simple univariate rules to forecast inflation, while the remainder uses rational expectations. In most specifications, the estimates are precise enough that the extreme of complete nonrationality can be ruled out at the 95 percent confidence level. These results are in contrast to that of Fuhrer (1997b), who found a point estimate of 0.8 and could not rule out complete nonrationality. As the sensitivity analysis of the paper suggested, estimates can be affected by the precise details of specification, and in some cases, I obtained results similar to Fuhrer's. However, once I allowed for a policy regime shift in 1979, the range of results tightened considerably, and I could reject both complete rationality and complete nonrationality in a broad range of specifications.

The estimates of the degree of nonrationality in expectations formation in this paper are qualitatively similar to estimates I obtained using survey measures of inflation expectations in Roberts (1998). In that earlier work, I found that about 40 percent of the population uses simple univariate rules for forecasting inflation. Taken together, the results of these two papers suggest that less-than-perfect-rationality is the most likely source of the failure of the New Keynesian sticky price model, with about half the population using simple univariate rules of thumb to forecast inflation, while the remainder use forecasting rules consistent with full rationality. 
Table 1

Estimates of New Keynesian Model Using One Lag and One Lead of Inflation Using the GDP price index as the measure of inflation

Quarterly data, 1957:1-1997:4

\begin{tabular}{|c|c|c|c|c|c|c|}
\hline \multicolumn{4}{|c|}{ Instruments: Lags 1 to 4 of measure of economic activity } & \multicolumn{3}{|c|}{$\begin{array}{l}\text { Instruments: Lags } 1 \text { to } 4 \text { of economic } \\
\text { activity and change in federal funds rate. }\end{array}$} \\
\hline & $\begin{array}{l}\text { Unemp. } \\
\text { rate }\end{array}$ & $\begin{array}{l}\text { Detrended } \\
\text { GDP }\end{array}$ & $\begin{array}{l}\text { Capacity } \\
\text { utilization }\end{array}$ & $\begin{array}{l}\text { Unemp. } \\
\text { rate }\end{array}$ & $\begin{array}{l}\text { Detrended } \\
\text { GDP }\end{array}$ & $\begin{array}{l}\text { Capacity } \\
\text { utilization }\end{array}$ \\
\hline Y & $\begin{array}{l}-.013 \\
(.009)\end{array}$ & $\begin{array}{l}.019 \\
(.016)\end{array}$ & $\begin{array}{l}.012 \\
(.008)\end{array}$ & $\begin{array}{l}-.009 \\
(.007)\end{array}$ & $\begin{array}{l}.010 \\
(.009)\end{array}$ & $\begin{array}{l}.003 \\
(.004)\end{array}$ \\
\hline$\omega$ & $\begin{array}{l}.70^{*} \\
(.14)\end{array}$ & $\begin{array}{l}.78^{*} \\
(.28)\end{array}$ & $\begin{array}{l}1.03^{*} \\
(.35)\end{array}$ & $\begin{array}{l}.61^{*} \\
(.10)\end{array}$ & $\begin{array}{l}.64^{*} \\
(.14)\end{array}$ & $\begin{array}{l}.60^{*} \\
(.19)\end{array}$ \\
\hline $\begin{array}{l}\text { J-test (prob. } \\
\text { level) }\end{array}$ & .32 & .60 & .76 & .75 & .68 & .70 \\
\hline Auto (1) & -.51 & -.46 & -.33 & -.54 & -.53 & -.54 \\
\hline
\end{tabular}

\begin{tabular}{|c|c|c|c|c|c|c|}
\hline \multicolumn{4}{|c|}{$\begin{array}{l}\text { Instruments: Lags } 1 \text { to } 4 \text { of measure of economic activity, } \\
\text { change in the federal funds rate, and change in inflation. }\end{array}$} & \multicolumn{3}{|c|}{$\begin{array}{l}\text { Instruments: Lags } 1 \text { to } 4 \text { of economic } \\
\text { activity and change in inflation. }\end{array}$} \\
\hline & $\begin{array}{l}\text { Unemp. } \\
\text { rate }\end{array}$ & $\begin{array}{l}\text { Detrended } \\
\text { GDP }\end{array}$ & $\begin{array}{l}\text { Capacity } \\
\text { utilization }\end{array}$ & $\begin{array}{l}\text { Unemp. } \\
\text { rate }\end{array}$ & $\begin{array}{l}\text { Detrended } \\
\text { GDP }\end{array}$ & $\begin{array}{l}\text { Capacity } \\
\text { utilization }\end{array}$ \\
\hline$Y$ & $\begin{array}{c}.004 \\
(.006)\end{array}$ & $\begin{array}{l}-.015^{*} \\
(.006)\end{array}$ & $\begin{array}{l}-.006 \\
(.004)\end{array}$ & $\begin{array}{l}.005 \\
(.007)\end{array}$ & $\begin{array}{l}-.015 \\
(.006)\end{array}$ & $\begin{array}{l}-.006 \\
(.004)\end{array}$ \\
\hline$\omega$ & $\begin{array}{l}.28^{*} \\
(.07)\end{array}$ & $\begin{array}{l}.17 \\
(.11)\end{array}$ & $\begin{array}{l}.15 \\
(.11)\end{array}$ & $\begin{array}{l}.26^{*} \\
(.10)\end{array}$ & $\begin{array}{l}.21^{\dagger} \\
(.11)\end{array}$ & $\begin{array}{l}.19 \\
(.12)\end{array}$ \\
\hline $\begin{array}{l}J \text {-test (prob. } \\
\text { level) }\end{array}$ & .69 & .56 & .90 & .78 & .67 & .96 \\
\hline Auto (1) & -.48 & -.42 & -.41 & -.47 & -.44 & -.43 \\
\hline
\end{tabular}

Notes: Numbers in parentheses are standard errors.

* indicates significance at the 5 percent level.

${ }^{+}$indicates significance at the 10 percent level.

$Y$ is the Phillips curve slope.

$\omega$ is the nonrational share. 
Table 2

Estimates of New Keynesian Model Using One Lag and One Lead of Inflation Using CPI as the measure of inflation

Quarterly data, 1957:1-1997:4

\begin{tabular}{|c|c|c|c|c|c|c|}
\hline \multicolumn{4}{|c|}{ Instruments: Lags 1 to 4 of measure of economic activity } & \multicolumn{3}{|c|}{$\begin{array}{l}\text { Instruments: Lags } 1 \text { to } 4 \text { of economic } \\
\text { activity and change in federal funds rate. }\end{array}$} \\
\hline & $\begin{array}{l}\text { Unemp. } \\
\text { rate }\end{array}$ & $\begin{array}{l}\text { Detrended } \\
\text { GDP }\end{array}$ & $\begin{array}{l}\text { Capacity } \\
\text { utilization }\end{array}$ & $\begin{array}{l}\text { Unemp. } \\
\text { rate }\end{array}$ & $\begin{array}{l}\text { Detrended } \\
\text { GDP }\end{array}$ & $\begin{array}{l}\text { Capacity } \\
\text { utilization }\end{array}$ \\
\hline $\mathrm{Y}$ & $\begin{array}{l}-.008 \\
(.008)\end{array}$ & $\begin{array}{l}.016 \\
(.009)\end{array}$ & $\begin{array}{l}.004 \\
(.004)\end{array}$ & $\begin{array}{l}-.007 \\
(.007)\end{array}$ & $\begin{array}{l}.011 \\
(.007)\end{array}$ & $\begin{array}{l}.004 \\
(.003)\end{array}$ \\
\hline$\omega$ & $\begin{array}{l}.43^{*} \\
(.12)\end{array}$ & $\begin{array}{l}.80^{*} \\
(.15)\end{array}$ & $\begin{array}{l}.53^{*} \\
(.16)\end{array}$ & $\begin{array}{l}.44^{*} \\
(.09)\end{array}$ & $\begin{array}{l}.68^{*} \\
(.12)\end{array}$ & $\begin{array}{l}.52^{*} \\
(.10)\end{array}$ \\
\hline $\begin{array}{l}J \text {-test (prob. } \\
\text { level) }\end{array}$ & .13 & .41 & .28 & .56 & .71 & .82 \\
\hline Auto (1) & -.50 & -.42 & -.51 & -.50 & -.47 & -.51 \\
\hline
\end{tabular}

\begin{tabular}{|c|c|c|c|c|c|c|}
\hline \multicolumn{4}{|c|}{$\begin{array}{l}\text { Instruments: Lags } 1 \text { to } 4 \text { of measure of economic activity, } \\
\text { change in the federal funds rate, and change in inflation. }\end{array}$} & \multicolumn{3}{|c|}{$\begin{array}{l}\text { Instruments: Lags } 1 \text { to } 4 \text { of economic } \\
\text { activity and change in inflation. }\end{array}$} \\
\hline & $\begin{array}{l}\text { Unemp. } \\
\text { rate }\end{array}$ & $\begin{array}{l}\text { Detrended } \\
\text { GDP }\end{array}$ & $\begin{array}{l}\text { Capacity } \\
\text { utilization }\end{array}$ & $\begin{array}{l}\text { Unemp. } \\
\text { rate }\end{array}$ & $\begin{array}{l}\text { Detrended } \\
\text { GDP }\end{array}$ & $\begin{array}{l}\text { Capacity } \\
\text { utilization }\end{array}$ \\
\hline Y & $\begin{array}{l}-.005 \\
(.006)\end{array}$ & $\begin{array}{l}-.002 \\
(.005)\end{array}$ & $\begin{array}{l}-.001 \\
(.002)\end{array}$ & $\begin{array}{l}-.002 \\
(.008)\end{array}$ & $\begin{array}{l}-.002 \\
(.005)\end{array}$ & $\begin{array}{l}-.001 \\
(.002)\end{array}$ \\
\hline$\omega$ & $\begin{array}{l}.33^{*} \\
(.06)\end{array}$ & $\begin{array}{l}.36^{*} \\
(.05)\end{array}$ & $\begin{array}{l}.31^{*} \\
(.05)\end{array}$ & $\begin{array}{l}.29^{*} \\
(.07)\end{array}$ & $\begin{array}{l}.34^{*} \\
(.06)\end{array}$ & $\begin{array}{l}.28^{*} \\
(.06)\end{array}$ \\
\hline $\begin{array}{l}J \text {-test (prob. } \\
\text { level) }\end{array}$ & .47 & .59 & .60 & .62 & .63 & .71 \\
\hline Auto (1) & -.46 & -.48 & -.46 & -.44 & -.47 & -.45 \\
\hline
\end{tabular}

Notes: Numbers in parentheses are standard errors.

* indicates significance at the 5 percent level.

${ }^{\dagger}$ indicates significance at the 10 percent level.

$Y$ is the Phillips curve slope.

$\omega$ is the nonrational share. 
Table 3

Estimates of New Keynesian Model Using Three Leads and Lags of Inflation Using the GDP price index as the measure of inflation

Quarterly data, 1957:1-1997:4

\begin{tabular}{|c|c|c|c|c|c|c|}
\hline \multicolumn{4}{|c|}{ Instruments: Lags 1 to 4 of measure of economic activity } & \multicolumn{3}{|c|}{$\begin{array}{l}\text { Instruments: Lags } 1 \text { to } 4 \text { of economic } \\
\text { activity and change in federal funds rate. }\end{array}$} \\
\hline & $\begin{array}{l}\text { Unemp. } \\
\text { rate }\end{array}$ & $\begin{array}{l}\text { Detrended } \\
\text { GDP }\end{array}$ & $\begin{array}{l}\text { Capacity } \\
\text { utilization }\end{array}$ & $\begin{array}{l}\text { Unemp. } \\
\text { rate }\end{array}$ & $\begin{array}{l}\text { Detrended } \\
\text { GDP }\end{array}$ & $\begin{array}{l}\text { Capacity } \\
\text { utilization }\end{array}$ \\
\hline Y & $\begin{array}{l}-.030^{*} \\
(.015)\end{array}$ & $\begin{array}{l}-.006 \\
(.028)\end{array}$ & $\begin{array}{l}.038^{\dagger} \\
(.020)\end{array}$ & $\begin{array}{l}-.020^{*} \\
(.010)\end{array}$ & $\begin{array}{l}.011 \\
(.013)\end{array}$ & $\begin{array}{l}.026^{*} \\
(.012)\end{array}$ \\
\hline$\omega$ & $\begin{array}{l}.76^{*} \\
(.12)\end{array}$ & $\begin{array}{l}.39 \\
(.35)\end{array}$ & $\begin{array}{l}1.25^{*} \\
(.33)\end{array}$ & $\begin{array}{l}.69^{*} \\
(.09)\end{array}$ & $\begin{array}{l}.62^{*} \\
(.15)\end{array}$ & $\begin{array}{l}1.15^{\star} \\
(.23)\end{array}$ \\
\hline $\begin{array}{l}J \text {-test (prob. } \\
\text { level) }\end{array}$ & .46 & .04 & .97 & .84 & .26 & .95 \\
\hline $\begin{array}{r}\text { Auto (1) } \\
(2) \\
(3) \\
(4)\end{array}$ & $\begin{array}{r}.03 \\
-.26 \\
-.24 \\
.14\end{array}$ & $\begin{array}{l}-.01 \\
-.30 \\
-.24 \\
.17\end{array}$ & $\begin{array}{l}.25 \\
-.07 \\
-.19 \\
.01\end{array}$ & $\begin{array}{l}-.02 \\
-.26 \\
-.27 \\
.17\end{array}$ & $\begin{array}{l}-.02 \\
-.31 \\
-.26 \\
.16\end{array}$ & $\begin{array}{r}.21 \\
-.11 \\
-.20 \\
.05\end{array}$ \\
\hline
\end{tabular}

\begin{tabular}{|c|c|c|c|c|c|c|}
\hline \multicolumn{4}{|c|}{$\begin{array}{l}\text { Instruments: Lags } 1 \text { to } 4 \text { of measure of economic activity; } \\
\text { change in the federal funds rate; and change in inflation. }\end{array}$} & \multicolumn{3}{|c|}{$\begin{array}{l}\text { Instruments: Lags } 1 \text { to } 4 \text { of measure of } \\
\text { economic activity and change in inflation. }\end{array}$} \\
\hline & $\begin{array}{l}\text { Unemp. } \\
\text { rate }\end{array}$ & $\begin{array}{l}\text { Detrended } \\
\quad \text { GDP }\end{array}$ & $\begin{array}{l}\text { Capacity } \\
\text { utilization }\end{array}$ & $\begin{array}{l}\text { Unemp. } \\
\text { rate }\end{array}$ & $\begin{array}{l}\text { Detrended } \\
\quad \text { GDP }\end{array}$ & $\begin{array}{l}\text { Capacity } \\
\text { utilization }\end{array}$ \\
\hline$Y$ & $\begin{array}{l}-.007 \\
(.010)\end{array}$ & $\begin{array}{l}-.013 \\
(.013)\end{array}$ & $\begin{array}{l}-.006 \\
(.007)\end{array}$ & $\begin{array}{l}-.008 \\
(.011)\end{array}$ & $\begin{array}{l}-.021 \\
(.021)\end{array}$ & $\begin{array}{l}-.005 \\
(.007)\end{array}$ \\
\hline$\omega$ & $\begin{array}{l}.50^{*} \\
(.08)\end{array}$ & $\begin{array}{l}.28^{\dagger} \\
(.16)\end{array}$ & $\begin{array}{l}.30^{*} \\
(.14)\end{array}$ & $\begin{array}{l}.52^{*} \\
(.09)\end{array}$ & $\begin{array}{l}.15 \\
(.25)\end{array}$ & $\begin{array}{l}.32^{\dagger} \\
(.16)\end{array}$ \\
\hline $\begin{array}{l}J \text {-test (prob. } \\
\text { level) }\end{array}$ & .80 & .46 & .89 & .85 & .58 & .92 \\
\hline $\begin{array}{r}\text { Auto (1) } \\
(2) \\
(3) \\
(4)\end{array}$ & $\begin{array}{l}-.03 \\
-.32 \\
-.26 \\
.17\end{array}$ & $\begin{array}{r}.03 \\
-.26 \\
-.22 \\
.16\end{array}$ & $\begin{array}{r}.02 \\
-.28 \\
-.23 \\
.16\end{array}$ & $\begin{array}{l}-.03 \\
-.32 \\
-.26 \\
.17\end{array}$ & $\begin{array}{r}.09 \\
-.20 \\
-.19 \\
.14\end{array}$ & $\begin{array}{r}.01 \\
-.28 \\
-.24 \\
.16\end{array}$ \\
\hline
\end{tabular}

Notes: Numbers in parentheses are standard errors.

* indicates significance at the 5 percent level.

${ }^{\dagger}$ indicates significance at the 10 percent level.

$Y$ is the Phillips curve slope.

$\omega$ is the nonrational share. 
Table 4

Estimates of New Keynesian Model Using Three Leads and Lags of Inflation Using CPI as the measure of inflation

Quarterly data, 1957:1-1997:4

\begin{tabular}{|c|c|c|c|c|c|c|}
\hline \multicolumn{4}{|c|}{ Instruments: Lags 1 to 4 of measure of economic activity } & \multicolumn{3}{|c|}{$\begin{array}{l}\text { Instruments: Lags } 1 \text { to } 4 \text { of economic } \\
\text { activity and change in federal funds rate. }\end{array}$} \\
\hline & $\begin{array}{l}\text { Unemp. } \\
\text { rate }\end{array}$ & $\begin{array}{l}\text { Detrended } \\
\text { GDP }\end{array}$ & $\begin{array}{l}\text { Capacity } \\
\text { utilization }\end{array}$ & $\begin{array}{l}\text { Unemp. } \\
\text { rate }\end{array}$ & $\begin{array}{l}\text { Detrended } \\
\text { GDP }\end{array}$ & $\begin{array}{l}\text { Capacity } \\
\text { utilization }\end{array}$ \\
\hline $\mathrm{Y}$ & $\begin{array}{l}-.016 \\
(.016)\end{array}$ & $\begin{array}{l}.036^{*} \\
(.018)\end{array}$ & $\begin{array}{l}.015 \\
(.010)\end{array}$ & $\begin{array}{l}-.016 \\
(.015)\end{array}$ & $\begin{array}{l}.036^{*} \\
(.015)\end{array}$ & $\begin{array}{l}.018^{*} \\
(.009)\end{array}$ \\
\hline$\omega$ & $\begin{array}{l}.37^{*} \\
(.12)\end{array}$ & $\begin{array}{l}.71^{*} \\
(.16)\end{array}$ & $\begin{array}{l}.63^{*} \\
(.17)\end{array}$ & $\begin{array}{l}.38^{*} \\
(.11)\end{array}$ & $\begin{array}{l}.74^{*} \\
(.15)\end{array}$ & $\begin{array}{l}.67^{*} \\
(.14)\end{array}$ \\
\hline $\begin{array}{l}J \text {-test (prob. } \\
\text { level) }\end{array}$ & .45 & .78 & .60 & .90 & .79 & .88 \\
\hline Auto (1) & .05 & .03 & .01 & .04 & .04 & .02 \\
\hline
\end{tabular}

\begin{tabular}{|c|c|c|c|c|c|c|}
\hline \multicolumn{4}{|c|}{$\begin{array}{l}\text { Instruments: Lags } 1 \text { to } 4 \text { of measure of economic activity, } \\
\text { change in the federal funds rate, and change in inflation. }\end{array}$} & \multicolumn{3}{|c|}{$\begin{array}{l}\text { Instruments: Lags } 1 \text { to } 4 \text { of economic } \\
\text { activity and change in inflation. }\end{array}$} \\
\hline & $\begin{array}{l}\text { Unemp. } \\
\text { rate }\end{array}$ & $\begin{array}{l}\text { Detrended } \\
\text { GDP }\end{array}$ & $\begin{array}{l}\text { Capacity } \\
\text { utilization }\end{array}$ & $\begin{array}{l}\text { Unemp. } \\
\text { rate }\end{array}$ & $\begin{array}{l}\text { Detrended } \\
\text { GDP }\end{array}$ & $\begin{array}{l}\text { Capacity } \\
\text { utilization }\end{array}$ \\
\hline$Y$ & $\begin{array}{l}-.019 \\
(.014)\end{array}$ & $\begin{array}{l}.031^{*} \\
(.015)\end{array}$ & $\begin{array}{l}.016^{*} \\
(.008)\end{array}$ & $\begin{array}{l}-.009 \\
(.015)\end{array}$ & $\begin{array}{l}.026 \dagger \\
(.016)\end{array}$ & $\begin{array}{l}.008 \\
(.009)\end{array}$ \\
\hline$\omega$ & $\begin{array}{l}.43^{*} \\
(.09)\end{array}$ & $\begin{array}{l}.63^{*} \\
(.12)\end{array}$ & $\begin{array}{l}.61^{*} \\
(.12)\end{array}$ & $\begin{array}{l}.34^{*} \\
(.11)\end{array}$ & $\begin{array}{l}.56^{*} \\
(.14)\end{array}$ & $\begin{array}{l}.48^{*} \\
(.16)\end{array}$ \\
\hline $\begin{array}{l}J \text {-test (prob. } \\
\text { level) }\end{array}$ & .56 & .56 & .53 & .73 & .60 & .61 \\
\hline Auto (1) & .03 & .02 & .01 & .06 & .01 & .02 \\
\hline
\end{tabular}

Notes: Numbers in parentheses are standard errors.

* indicates significance at the 5 percent level.

${ }^{+}$indicates significance at the 10 percent level.

$Y$ is the Phillips curve slope.

$\omega$ is the nonrational share. 
Table 5

Estimates Using Cross Instruments for Economic Activity

Using specification with three leads and lags of inflation

Instruments: Lags 1 to 4 of economic activity and change in federal funds rate Quarterly data, 1957:1-1997:4

\begin{tabular}{|c|c|c|c|c|}
\hline \multirow[b]{2}{*}{ Instrument: } & \multicolumn{2}{|c|}{$\begin{array}{l}\text { Using GDP price index as measure of } \\
\text { inflation }\end{array}$} & \multicolumn{2}{|c|}{ Using CPI as measure of inflation } \\
\hline & Detrended GDP & $\begin{array}{l}\text { Unemployment } \\
\text { rate }\end{array}$ & Detrended GDP & $\begin{array}{l}\text { Unemployment } \\
\text { rate }\end{array}$ \\
\hline $\begin{array}{l}\text { Activity variable in } \\
\text { model: }\end{array}$ & Unemployment rate & Detrended GDP & $\begin{array}{c}\text { Unemployment } \\
\text { rate }\end{array}$ & Detrended GDP \\
\hline $\mathrm{Y}$ & $\begin{array}{l}-.037 \\
(.030)\end{array}$ & $\begin{array}{l}.054 \\
(.036)\end{array}$ & $\begin{array}{l}-.070^{*} \\
(.032)\end{array}$ & $\begin{array}{l}.031 \\
(.022)\end{array}$ \\
\hline$\omega$ & $\begin{array}{l}.79^{*} \\
(.17)\end{array}$ & $\begin{array}{l}1.09^{*} \\
(.27)\end{array}$ & $\begin{array}{l}.63^{*} \\
(.13)\end{array}$ & $\begin{array}{l}.51^{*} \\
(.17)\end{array}$ \\
\hline$J$-test (prob. level) & .26 & .84 & .78 & .91 \\
\hline $\begin{array}{r}\text { Auto (1) } \\
(2) \\
(3) \\
(4)\end{array}$ & $\begin{array}{r}.05 \\
-.24 \\
-.24 \\
.14\end{array}$ & $\begin{array}{r}.20 \\
-.12 \\
-.19 \\
.07\end{array}$ & $\begin{array}{r}.06 \\
-.33 \\
-.09 \\
.02\end{array}$ & $\begin{array}{l}.03 \\
-.37 \\
-.13 \\
-.01\end{array}$ \\
\hline
\end{tabular}

Notes: Numbers in parentheses are standard errors.

* indicates significance at the 5 percent level.

${ }^{\dagger}$ indicates significance at the 10 percent level.

$Y$ is the Phillips curve slope.

$\omega$ is the nonrational share. 
Table 6

Estimates Using Instruments that Split in 1980

Using specification with three leads and lags of inflation

Instruments: Lags 1 to 4 of economic activity and change in federal funds rate

Quarterly data, 1957:1-1997:4

\begin{tabular}{|c|c|c|c|c|c|}
\hline & \multicolumn{2}{|c|}{ Using as instrument for activity: } \\
\hline \multicolumn{4}{|c|}{ Measure of inflation: CPI } & Detrended GDP & Unemp. rate \\
\hline & $\begin{array}{l}\text { Unemp. } \\
\text { rate }\end{array}$ & $\begin{array}{c}\text { Detrended } \\
\text { GDP }\end{array}$ & $\begin{array}{l}\text { Capacity } \\
\text { utilization }\end{array}$ & $\begin{array}{l}\text { Unemp. } \\
\text { rate }\end{array}$ & $\begin{array}{l}\text { Detrended } \\
\text { GDP }\end{array}$ \\
\hline $\mathrm{Y}$ & $\begin{array}{l}-.021^{\dagger} \\
(.011)\end{array}$ & $\begin{array}{c}.026^{*} \\
(.011)\end{array}$ & $\begin{array}{l}.014^{*} \\
(.006)\end{array}$ & $\begin{array}{l}-.044^{*} \\
(.020)\end{array}$ & $\begin{array}{r}.026^{\dagger} \\
(.015)\end{array}$ \\
\hline$\omega$ & $\begin{array}{l}.47^{*} \\
(.07)\end{array}$ & $\begin{array}{l}.58^{*} \\
(.07)\end{array}$ & $\begin{array}{l}.67^{*} \\
(.09)\end{array}$ & $\begin{array}{l}.58^{*} \\
(.07)\end{array}$ & $\begin{array}{l}.53^{*} \\
(.15)\end{array}$ \\
\hline $\begin{array}{l}J \text {-test (prob. } \\
\text { level) }\end{array}$ & .85 & .87 & .87 & .87 & .83 \\
\hline Auto (1) & $\begin{array}{r}.02 \\
-.39 \\
-.14 \\
-.02\end{array}$ & $\begin{array}{r}.02 \\
-.38 \\
-.13 \\
-.01\end{array}$ & $\begin{array}{r}.02 \\
-.38 \\
-.14 \\
-.03\end{array}$ & $\begin{array}{r}.02 \\
-.38 \\
-.13 \\
-.01\end{array}$ & $\begin{array}{r}.02 \\
-.39 \\
-.14 \\
-.02\end{array}$ \\
\hline
\end{tabular}

\begin{tabular}{|c|c|c|c|c|c|}
\hline & \multicolumn{2}{|c|}{ Using as instrument for activity: } \\
\hline \multicolumn{4}{|c|}{ Measure of inflation: GDP price index } & Detrended GDP & Unemp. rate \\
\hline & $\begin{array}{l}\text { Unemp. } \\
\text { rate }\end{array}$ & $\begin{array}{l}\text { Detrended } \\
\text { GDP }\end{array}$ & $\begin{array}{l}\text { Capacity } \\
\text { utilization }\end{array}$ & $\begin{array}{l}\text { Unemp. } \\
\text { rate }\end{array}$ & $\begin{array}{l}\text { Detrended } \\
\text { GDP }\end{array}$ \\
\hline Y & $\begin{array}{l}-.019^{*} \\
(.006)\end{array}$ & $\begin{array}{l}.002 \\
(.006)\end{array}$ & $\begin{array}{l}.006^{*} \\
(.003)\end{array}$ & $\begin{array}{l}-.014^{\dagger} \\
(.008)\end{array}$ & $\begin{array}{l}.019^{\star} \\
(.007)\end{array}$ \\
\hline$\omega$ & $\begin{array}{l}.60^{*} \\
(.05)\end{array}$ & $\begin{array}{l}.49^{*} \\
(.06)\end{array}$ & $\begin{array}{l}.61^{*} \\
(.06)\end{array}$ & $\begin{array}{l}.52^{*} \\
(.05)\end{array}$ & $\begin{array}{l}.65^{*} \\
(.06)\end{array}$ \\
\hline $\begin{array}{l}\text { J-test (prob. } \\
\text { level) }\end{array}$ & .91 & .66 & .98 & .66 & .92 \\
\hline Auto (1) & $\begin{array}{r}-.05 \\
-.28 \\
-.28 \\
.18\end{array}$ & $\begin{array}{r}-.03 \\
-.32 \\
-.25 \\
.17\end{array}$ & $\begin{array}{r}-.02 \\
-.31 \\
-.26 \\
.16\end{array}$ & $\begin{array}{r}-.03 \\
-.32 \\
-.26 \\
.17\end{array}$ & $\begin{array}{r}-.01 \\
-.31 \\
-.25 \\
.16\end{array}$ \\
\hline
\end{tabular}

Notes: Numbers in parentheses are standard errors.

* indicates significance at the 5 percent level.

${ }^{\dagger}$ indicates significance at the 10 percent level.

$Y$ is the Phillips curve slope.

$\omega$ is the nonrational share. 
Table 7

Estimates of New Keynesian Model with Serially Correlated Errors

Using one lead and GDP price index as the measure of inflation

Instruments: Lags 1 to 4 of economic activity and change in federal funds rate

\begin{tabular}{|c|c|c|c|c|c|c|}
\hline \multirow{2}{*}{$\begin{array}{l}\text { Estimation } \\
\text { period: }\end{array}$} & \multicolumn{3}{|c|}{$1957: 1-1997: 4$} & \multicolumn{3}{|c|}{$1980: 2-1995: 2$} \\
\hline & $\begin{array}{l}\text { Unemp. } \\
\text { rate }\end{array}$ & $\begin{array}{c}\text { Detrended } \\
\text { GDP }\end{array}$ & $\begin{array}{l}\text { Capacity } \\
\text { utilization }\end{array}$ & $\begin{array}{l}\text { Unemp. } \\
\text { rate }\end{array}$ & $\begin{array}{c}\text { Detrended } \\
\text { GDP }\end{array}$ & $\begin{array}{l}\text { Capacity } \\
\text { utilization }\end{array}$ \\
\hline Y & $\begin{array}{l}.020^{*} \\
(.007)\end{array}$ & $\begin{array}{l}-.015^{*} \\
(.007)\end{array}$ & $\begin{array}{l}-.011^{*} \\
(.004)\end{array}$ & $\begin{array}{c}.029^{*} \\
(.008)\end{array}$ & $\begin{array}{l}-.018^{*} \\
(.003)\end{array}$ & $\begin{array}{l}-.009^{*} \\
(.003)\end{array}$ \\
\hline$\phi$ & $\begin{array}{l}-.02 \\
(.14)\end{array}$ & $\begin{array}{l}.20 \\
(.19)\end{array}$ & $\begin{array}{l}.25 \\
(.21)\end{array}$ & $\begin{array}{l}.11 \\
(.09)\end{array}$ & $\begin{array}{l}-.23^{*} \\
(.10)\end{array}$ & $\begin{array}{l}.01 \\
(.19)\end{array}$ \\
\hline $\begin{array}{l}J \text {-test (prob. } \\
\text { level) }\end{array}$ & .53 & .81 & .85 & .79 & .73 & .94 \\
\hline $\begin{array}{r}\text { Auto (1) } \\
(2) \\
(3) \\
(4)\end{array}$ & $\begin{array}{r}-.30 \\
-.15 \\
.03 \\
.08\end{array}$ & $\begin{array}{l}-.43 \\
-.07 \\
.03 \\
.06\end{array}$ & $\begin{array}{r}-.46 \\
-.06 \\
.02 \\
.05\end{array}$ & $\begin{array}{l}-.32 \\
-.31 \\
.31 \\
.06\end{array}$ & $\begin{array}{r}-.11 \\
-.36 \\
.26 \\
.15\end{array}$ & $\begin{array}{r}-.27 \\
-.31 \\
.29 \\
.03\end{array}$ \\
\hline
\end{tabular}

Notes: Numbers in parentheses are standard errors.

* indicates significance at the 5 percent level.

${ }^{\dagger}$ indicates significance at the 10 percent level.

$Y$ is the Phillips curve slope.

$\phi$ is the first-order autocorrelation coefficient. 
Table 8

Estimates of Model Conditional on Labor's Share as a Proxy for Labor Costs Using one lead and lag and GDP price index as the measure of inflation Quarterly data, 1957:1-1997:4

\begin{tabular}{|c|c|c|c|c|c|c|}
\hline \multicolumn{7}{|c|}{ Base instruments: Lags 1 to 4 of measure of economic activity and change in federal funds rate. } \\
\hline & \multicolumn{3}{|c|}{ Instruments: Base only } & \multicolumn{3}{|c|}{$\begin{array}{l}\text { Instruments: Base plus lagged labor } \\
\text { share }\end{array}$} \\
\hline $\begin{array}{l}\text { Measure of } \\
\text { activity used } \\
\text { as instrument: }\end{array}$ & $\begin{array}{l}\text { Unemp. } \\
\text { rate }\end{array}$ & $\begin{array}{l}\text { Detrended } \\
\text { GDP }\end{array}$ & $\begin{array}{l}\text { Capacity } \\
\text { utilization }\end{array}$ & $\begin{array}{l}\text { Unemp. } \\
\text { rate }\end{array}$ & $\begin{array}{l}\text { Detrended } \\
\text { GDP }\end{array}$ & $\begin{array}{r}\text { Capacity } \\
\text { utilization }\end{array}$ \\
\hline Labor's share & $\begin{array}{l}.005 \\
(.010)\end{array}$ & $\begin{array}{l}.021^{\dagger} \\
(.011)\end{array}$ & $\begin{array}{l}.009 \\
(.012)\end{array}$ & $\begin{array}{l}.007 \\
(.006)\end{array}$ & $\begin{array}{l}.008 \\
(.006)\end{array}$ & $\begin{array}{l}.012^{\dagger} \\
(.007)\end{array}$ \\
\hline$\omega$ & $\begin{array}{l}.50^{*} \\
(.07)\end{array}$ & $\begin{array}{l}.38^{*} \\
(.08)\end{array}$ & $\begin{array}{l}.42^{*} \\
(.08)\end{array}$ & $\begin{array}{l}.42^{*} \\
(.06)\end{array}$ & $\begin{array}{l}.40^{*} \\
(.06)\end{array}$ & $\begin{array}{l}.36^{*} \\
(.08)\end{array}$ \\
\hline $\begin{array}{l}\text { J-test (prob. } \\
\text { level) }\end{array}$ & .64 & .78 & .65 & .63 & .64 & .71 \\
\hline $\begin{array}{r}\text { Auto (1) } \\
(2) \\
(3) \\
(4)\end{array}$ & $\begin{array}{r}-.55 \\
.04 \\
-.05 \\
.13\end{array}$ & $\begin{array}{r}-.52 \\
.05 \\
-.04 \\
.12\end{array}$ & $\begin{array}{r}-.54 \\
.04 \\
-.05 \\
.12\end{array}$ & $\begin{array}{r}-.54 \\
.04 \\
-.05 \\
.12\end{array}$ & $\begin{array}{l}-.54 \\
.04 \\
-.05 \\
.12\end{array}$ & $\begin{array}{r}-.52 \\
.03 \\
-.05 \\
.12\end{array}$ \\
\hline
\end{tabular}

\begin{tabular}{|c|c|c|c|c|c|c|}
\hline \multicolumn{7}{|c|}{ Base instruments: Lags 1 to 4 of measure of economic activity and change in inflation. } \\
\hline & \multicolumn{3}{|c|}{ Instruments: Base only } & \multicolumn{3}{|c|}{$\begin{array}{c}\text { Instruments: Base plus lagged labor } \\
\text { share }\end{array}$} \\
\hline $\begin{array}{l}\text { Measure of } \\
\text { activity used } \\
\text { as instrument: }\end{array}$ & $\begin{array}{l}\text { Unemp. } \\
\text { rate }\end{array}$ & $\begin{array}{l}\text { Detrended } \\
\text { GDP }\end{array}$ & $\begin{array}{l}\text { Capacity } \\
\text { utilization }\end{array}$ & $\begin{array}{l}\text { Unemp. } \\
\text { rate }\end{array}$ & $\begin{array}{l}\text { Detrended } \\
\text { GDP }\end{array}$ & $\begin{array}{l}\text { Capacity } \\
\text { utilization }\end{array}$ \\
\hline Labor's share & $\begin{array}{l}-.010 \\
(.017)\end{array}$ & $\begin{array}{l}.037^{*} \\
(.015)\end{array}$ & $\begin{array}{l}.019 \\
(.025)\end{array}$ & $\begin{array}{l}.011 \\
(.007)\end{array}$ & $\begin{array}{l}.013^{*} \\
(.007)\end{array}$ & $\begin{array}{l}.014^{\dagger} \\
(.008)\end{array}$ \\
\hline$\omega$ & $\begin{array}{r}.34^{*} \\
(.09) \\
\end{array}$ & $\begin{array}{l}.21^{*} \\
(.10)\end{array}$ & $\begin{array}{l}.25^{*} \\
(.11)\end{array}$ & $\begin{array}{l}.27^{*} \\
(.08)\end{array}$ & $\begin{aligned} .28^{*} \\
(.07) \\
\end{aligned}$ & $\begin{array}{l}.24^{*} \\
(.07)\end{array}$ \\
\hline $\begin{array}{l}J \text {-test (prob. } \\
\text { level) }\end{array}$ & .30 & .37 & .57 & .52 & .43 & .71 \\
\hline $\begin{array}{r}\text { Auto (1) } \\
(2) \\
(3) \\
(4)\end{array}$ & $\begin{array}{r}-.50 \\
.03 \\
-.04 \\
.12\end{array}$ & $\begin{array}{r}-.39 \\
.02 \\
-.01 \\
.12\end{array}$ & $\begin{array}{r}-.45 \\
.01 \\
-.03 \\
.11\end{array}$ & $\begin{array}{r}-.47 \\
.01 \\
-.04 \\
.11\end{array}$ & $\begin{array}{l}-.48 \\
.01 \\
-.04 \\
.11\end{array}$ & $\begin{array}{r}-.45 \\
.00 \\
-.04 \\
.11\end{array}$ \\
\hline
\end{tabular}

Notes: Numbers in parentheses are standard errors.

* indicates significance at the 5 percent level.

${ }^{\dagger}$ indicates significance at the 10 percent level.

$\omega$ is the nonrational share. 
Table 9

Estimates of Model Conditional on Labor's Share as a Proxy for Labor Costs Using three leads and lags and GDP price index as the measure of inflation Quarterly data, 1957:1-1997:4

\begin{tabular}{|c|c|c|c|c|c|c|}
\hline \multicolumn{7}{|c|}{ Base instruments: Lags 1 to 4 of measure of economic activity and change in federal funds rate. } \\
\hline & \multicolumn{3}{|c|}{ Base instruments only } & \multicolumn{3}{|c|}{ Base instruments plus labor's share } \\
\hline $\begin{array}{l}\text { Measure of } \\
\text { activity used } \\
\text { as instrument: }\end{array}$ & $\begin{array}{l}\text { Unemp. } \\
\text { rate }\end{array}$ & $\begin{array}{l}\text { Detrended } \\
\text { GDP }\end{array}$ & $\begin{array}{l}\text { Capacity } \\
\text { utilization }\end{array}$ & $\begin{array}{l}\text { Unemp. } \\
\text { rate }\end{array}$ & $\begin{array}{l}\text { Detrended } \\
\text { GDP }\end{array}$ & $\begin{array}{l}\text { Capacity } \\
\text { utilization }\end{array}$ \\
\hline Labor's share & $\begin{array}{l}.022 \\
(.018)\end{array}$ & $\begin{array}{l}.053^{*} \\
(.016)\end{array}$ & $\begin{array}{l}.019 \\
(.017)\end{array}$ & $\begin{array}{r}.017^{\dagger} \\
(.009)\end{array}$ & $\begin{array}{l}.017^{*} \\
(.009)\end{array}$ & $\begin{array}{l}.019^{\star} \\
(.008)\end{array}$ \\
\hline$\omega$ & $\begin{array}{l}.46^{*} \\
(.06)\end{array}$ & $\begin{array}{l}.33^{*} \\
(.10)\end{array}$ & $\begin{array}{l}.40^{*} \\
(.07)\end{array}$ & $\begin{array}{l}.40^{*} \\
(.05)\end{array}$ & $\begin{array}{l}.39^{*} \\
(.06)\end{array}$ & $\begin{array}{l}.40^{*} \\
(.05)\end{array}$ \\
\hline $\begin{array}{l}J \text {-test (prob. } \\
\text { level) }\end{array}$ & .56 & .68 & .65 & .55 & .48 & .74 \\
\hline $\begin{array}{r}\text { Auto (1) } \\
(2) \\
(3) \\
(4)\end{array}$ & $\begin{array}{l}-.03 \\
-.30 \\
-.25 \\
.17\end{array}$ & $\begin{array}{r}.05 \\
-.20 \\
-.17 \\
.17\end{array}$ & $\begin{array}{l}-.02 \\
-.30 \\
-.24 \\
.17\end{array}$ & $\begin{array}{l}-.02 \\
-.30 \\
-.24 \\
.17\end{array}$ & $\begin{array}{l}-.02 \\
-.30 \\
-.24 \\
.17\end{array}$ & $\begin{array}{l}-.02 \\
-.30 \\
-.24 \\
.17\end{array}$ \\
\hline
\end{tabular}

\begin{tabular}{|c|c|c|c|c|c|c|}
\hline \multicolumn{7}{|c|}{ Base instruments: Lags 1 to 4 of measure of economic activity and change in inflation. } \\
\hline & \multicolumn{3}{|c|}{ Base instruments only } & \multicolumn{3}{|c|}{ Base instruments plus labor's share } \\
\hline $\begin{array}{l}\text { Measure of } \\
\text { activity used } \\
\text { as instrument: }\end{array}$ & $\begin{array}{l}\text { Unemp. } \\
\text { rate }\end{array}$ & $\begin{array}{l}\text { Detrended } \\
\text { GDP }\end{array}$ & $\begin{array}{l}\text { Capacity } \\
\text { utilization }\end{array}$ & $\begin{array}{l}\text { Unemp. } \\
\text { rate }\end{array}$ & $\begin{array}{l}\text { Detrended } \\
\text { GDP }\end{array}$ & $\begin{array}{l}\text { Capacity } \\
\text { utilization }\end{array}$ \\
\hline Labor's share & $\begin{array}{l}.010 \\
(.026)\end{array}$ & $\begin{array}{l}.065^{*} \\
(.020)\end{array}$ & $\begin{array}{l}.043^{\dagger} \\
(.026)\end{array}$ & $\begin{array}{r}.015^{\dagger} \\
(.009)\end{array}$ & $\begin{array}{l}.019^{\star} \\
(.009)\end{array}$ & $\begin{array}{l}.015^{\dagger} \\
(.008)\end{array}$ \\
\hline$\omega$ & $\begin{array}{l}.38^{*} \\
(.09)\end{array}$ & $\begin{array}{l}.29^{*} \\
(.11)\end{array}$ & $\begin{array}{l}.31^{*} \\
(.09)\end{array}$ & $\begin{array}{l}.35^{*} \\
(.05)\end{array}$ & $\begin{array}{r}.35^{*} \\
(.06)\end{array}$ & $\begin{array}{l}.39^{*} \\
(.05)\end{array}$ \\
\hline $\begin{array}{l}J \text {-test (prob. } \\
\text { level) }\end{array}$ & .53 & .37 & .71 & .55 & .41 & .67 \\
\hline $\begin{array}{r}\text { Auto (1) } \\
(2) \\
(3) \\
(4)\end{array}$ & $\begin{array}{l}-.01 \\
-.29 \\
-.24 \\
.17\end{array}$ & $\begin{array}{r}.10 \\
-.14 \\
-.13 \\
.18\end{array}$ & $\begin{array}{r}.04 \\
-.22 \\
-.19 \\
.16\end{array}$ & $\begin{array}{r}.00 \\
-.28 \\
-.23 \\
.16\end{array}$ & $\begin{array}{r}.00 \\
-.28 \\
-.23 \\
.16\end{array}$ & $\begin{array}{l}-.01 \\
-.30 \\
-.24 \\
.17\end{array}$ \\
\hline
\end{tabular}

Notes: Numbers in parentheses are standard errors.

* indicates significance at the 5 percent level.

${ }^{\dagger}$ indicates significance at the 10 percent level.

$\omega$ is the nonrational share. 
Table 10

Estimates of Model Conditional on Labor's Share as a Proxy for Labor Costs Using three leads and lags and CPI as the measure of inflation

Quarterly data, 1957:1-1997:4

\begin{tabular}{|c|c|c|c|c|c|c|}
\hline \multicolumn{7}{|c|}{ Base instruments: Lags 1 to 4 of measure of economic activity and change in federal funds rate. } \\
\hline & \multicolumn{3}{|c|}{ Base instruments only } & \multicolumn{3}{|c|}{ Base instruments plus labor's share } \\
\hline $\begin{array}{l}\text { Measure of } \\
\text { activity used } \\
\text { as instrument: }\end{array}$ & $\begin{array}{l}\text { Unemp. } \\
\text { rate }\end{array}$ & $\begin{array}{l}\text { Detrended } \\
\text { GDP }\end{array}$ & $\begin{array}{c}\text { Capacity } \\
\text { utilization }\end{array}$ & $\begin{array}{l}\text { Unemp. } \\
\text { rate }\end{array}$ & $\begin{array}{l}\text { Detrended } \\
\text { GDP }\end{array}$ & $\begin{array}{l}\text { Capacity } \\
\text { utilization }\end{array}$ \\
\hline Labor's share & $\begin{array}{l}.018 \\
(.039)\end{array}$ & $\begin{array}{l}.059^{*} \\
(.028)\end{array}$ & $\begin{array}{l}.008 \\
(.039)\end{array}$ & $\begin{array}{l}.034^{*} \\
(.015)\end{array}$ & $\begin{array}{l}.017^{\dagger} \\
(.010)\end{array}$ & $\begin{array}{l}.024^{*} \\
(.013)\end{array}$ \\
\hline$\omega$ & $\begin{array}{l}.23^{\dagger} \\
(.14)\end{array}$ & $\begin{array}{l}.29^{*} \\
(.12)\end{array}$ & $\begin{array}{l}.37^{*} \\
(.12)\end{array}$ & $\begin{array}{l}.14^{\dagger} \\
(.08)\end{array}$ & $\begin{array}{l}.37^{*} \\
(.06)\end{array}$ & $\begin{array}{l}.30^{*} \\
(.08)\end{array}$ \\
\hline $\begin{array}{l}J \text {-test (prob. } \\
\text { level) }\end{array}$ & .88 & .76 & .58 & .65 & .52 & .66 \\
\hline $\begin{array}{r}\text { Auto (1) } \\
(2) \\
(3) \\
(4)\end{array}$ & $\begin{array}{l}.10 \\
-.30 \\
-.10 \\
-.02\end{array}$ & $\begin{array}{r}.08 \\
-.30 \\
-.08 \\
.01\end{array}$ & $\begin{array}{l}.04 \\
-.37 \\
-.13 \\
-.02\end{array}$ & $\begin{array}{l}.15 \\
-.23 \\
-.07 \\
-.01\end{array}$ & $\begin{array}{l}.04 \\
-.37 \\
-.13 \\
-.02\end{array}$ & $\begin{array}{l}.06 \\
-.34 \\
-.12 \\
-.02\end{array}$ \\
\hline
\end{tabular}

\begin{tabular}{|c|c|c|c|c|c|c|}
\hline \multicolumn{7}{|c|}{ Base instruments: Lags 1 to 4 of measure of economic activity and change in inflation. } \\
\hline & \multicolumn{3}{|c|}{ Base instruments only } & \multicolumn{3}{|c|}{ Base instruments plus labor's share } \\
\hline $\begin{array}{l}\text { Measure of } \\
\text { activity used } \\
\text { as instrument: }\end{array}$ & $\begin{array}{l}\text { Unemp. } \\
\text { rate }\end{array}$ & $\begin{array}{l}\text { Detrended } \\
\text { GDP }\end{array}$ & $\begin{array}{l}\text { Capacity } \\
\text { utilization }\end{array}$ & $\begin{array}{l}\text { Unemp. } \\
\text { rate }\end{array}$ & $\begin{array}{l}\text { Detrended } \\
\text { GDP }\end{array}$ & $\begin{array}{l}\text { Capacity } \\
\text { utilization }\end{array}$ \\
\hline Labor's share & $\begin{array}{l}.018 \\
(.050)\end{array}$ & $\begin{array}{l}.069^{*} \\
(.031)\end{array}$ & $\begin{array}{l}.041 \\
(.049)\end{array}$ & $\begin{array}{l}.031^{*} \\
(.016)\end{array}$ & $\begin{array}{l}.021^{*} \\
(.011)\end{array}$ & $\begin{array}{l}.026^{\dagger} \\
(.014)\end{array}$ \\
\hline$\omega$ & $\begin{array}{r}.22^{*} \\
(.16)\end{array}$ & $\begin{array}{l}.20^{*} \\
(.12)\end{array}$ & $\begin{array}{c}.24 \\
(.15)\end{array}$ & $\begin{array}{l}.16^{\dagger} \\
(.09)\end{array}$ & $\begin{array}{c}.32^{*} \\
(.07)\end{array}$ & $\begin{array}{l}.26^{*} \\
(.08)\end{array}$ \\
\hline $\begin{array}{l}J \text {-test (prob. } \\
\text { level) }\end{array}$ & .37 & .33 & .25 & .55 & .45 & .51 \\
\hline $\begin{array}{r}\text { Auto (1) } \\
(2) \\
(3) \\
(4)\end{array}$ & $\begin{array}{l}.11 \\
-.29 \\
-.10 \\
-.02\end{array}$ & $\begin{array}{r}.14 \\
-.23 \\
-.05 \\
.02\end{array}$ & $\begin{array}{l}.09 \\
-.30 \\
-.10 \\
-.01\end{array}$ & $\begin{array}{l}.14 \\
-.25 \\
-.08 \\
-.01\end{array}$ & $\begin{array}{l}.05 \\
-.35 \\
-.12 \\
-.02\end{array}$ & $\begin{array}{l}.08 \\
-.32 \\
-.11 \\
-.02\end{array}$ \\
\hline
\end{tabular}

Notes: Numbers in parentheses are standard errors.

* indicates significance at the 5 percent level.

${ }^{\dagger}$ indicates significance at the 10 percent level.

$\omega$ is the nonrational share. 


\section{Table 11}

Disaggregating Labor's Share in the Partial Adjustment Model

Using specification with three leads and lags of inflation

Quarterly data, 1957:1-1997:4

\begin{tabular}{|l|c|c||c|c|}
\hline \multicolumn{2}{|l|}{ Instruments: Lags 1 to 4 of detrended GDP; labor's share; and additional instrument as indicated. } \\
\hline $\begin{array}{l}\text { Inflation } \\
\text { measure: }\end{array}$ & \multicolumn{2}{|c|}{ CPI } & \multicolumn{2}{c|}{ GDP price index } \\
\hline $\begin{array}{l}\text { Additional } \\
\text { instrument: }\end{array}$ & $\begin{array}{c}\text { Change in fed. } \\
\text { funds rate }\end{array}$ & Change in inflation & $\begin{array}{c}\text { Change in fed. } \\
\text { funds rate }\end{array}$ & Change in inflation \\
\hline $\begin{array}{l}\text { Labor's share with } \\
\text { detrended OPH }\end{array}$ & -.005 & -.012 & -.008 & -.036 \\
\hline Detrended OPH & $(.025)$ & $(.034)$ & $(.015)$ & $(.022)$ \\
\hline & -.066 & $-.080^{\dagger}$ & $-.049^{*}$ & $-.084^{*}$ \\
\hline & $(.047)$ & $(.049)$ & $(.016)$ & $.022)$ \\
\hline J-test (prob. level) & .19 & .12 & $.24^{*}$ & .07 \\
\hline Auto (1) & $(.15)$ & $(.18)$ & $. .09)$ & $(.10)$ \\
(2) & .45 & & .53 & .72 \\
\hline (3) & .08 & .11 & .03 & .13 \\
(4) & -.32 & -.28 & -.26 & -.20 \\
\hline
\end{tabular}

Instruments: Lags 1 to 4 of detrended GDP; labor's share; detrended $\mathrm{OPH}$; and additional instrument as indicated.

\begin{tabular}{|l|c|c||c|c|}
\hline $\begin{array}{l}\text { Inflation } \\
\text { measure: }\end{array}$ & \multicolumn{2}{|c||}{ CPI } & \multicolumn{2}{c|}{ GDP price index } \\
\hline $\begin{array}{l}\text { Additional } \\
\text { instrument: }\end{array}$ & $\begin{array}{c}\text { Change in fed. } \\
\text { funds rate }\end{array}$ & Change in inflation & $\begin{array}{c}\text { Change in fed. } \\
\text { funds rate }\end{array}$ & Change in inflation \\
\hline $\begin{array}{l}\text { Labor's share with } \\
\text { detrended OPH }\end{array}$ & .013 & .011 & .009 & .004 \\
\hline Detrended OPH & $(.011)$ & $(.013)$ & $(.010)$ & $(.010)$ \\
\hline W & -.031 & $-.036^{\dagger}$ & $-.030^{*}$ & $-.037^{*}$ \\
& $(.019)$ & $(.019)$ & $(.013)$ & $(.012)$ \\
\hline J-test (prob. level) & $.30^{*}$ & $.26^{*}$ & $.24^{*}$ & .31 \\
\hline Auto (1) & $(.09)$ & $(.10)$ & $(.09)$ & $(.06)$ \\
$(2)$ & .76 & .70 & .74 & .69 \\
\hline (3) & .05 & .06 & -.01 & .00 \\
$(4)$ & -.35 & -.34 & -.29 & -.28 \\
\hline
\end{tabular}

Notes: Numbers in parentheses are standard errors.

* indicates significance at the 5 percent level.

${ }^{\dagger}$ indicates significance at the 10 percent level.

$\mathrm{OPH}$ is output per hour, or average labor productivity. 
Table 12

Comparing Economic Activity and Detrended Labor Productivity in the Partial Adjustment Model Using specification with three leads and lags of inflation and CPI

Quarterly data, 1957:1-1997:4

\begin{tabular}{|l|c|c||c|c|}
\hline \multirow{2}{*}{ Instruments: Lags 1 to 4 of detrended GDP; and of additional instruments as indicated. } \\
\hline \multirow{3}{*}{$\begin{array}{l}\text { Additional } \\
\text { instruments: }\end{array}$} & \multicolumn{2}{|c|}{ Change in federal funds rate } & \multicolumn{2}{c|}{ Change in inflation } \\
\cline { 2 - 5 } & $\begin{array}{c}\text { Without detrended } \\
\text { OPH }\end{array}$ & $\begin{array}{c}\text { With detrended } \\
\text { OPH }\end{array}$ & $\begin{array}{c}\text { Without detrended } \\
\text { OPH }\end{array}$ & $\begin{array}{c}\text { With detrended } \\
\text { OPH }\end{array}$ \\
\hline \multirow{2}{*}{ Economic activity } & $.034^{*}$ & $.030^{*}$ & .006 & .017 \\
& $(.015)$ & $(.015)$ & $(.015)$ & $(.016)$ \\
\hline Detrended OPH & -.013 & .028 & $-.101^{*}$ & -.022 \\
& $(.046)$ & $(.041)$ & $(.047)$ & $(.029)$ \\
\hline W & $.67^{*}$ & $.78^{*}$ & $.10^{*}$ & $.43^{*}$ \\
& $(.24)$ & $(.25)$ & $(.23)$ & $(.22)$ \\
\hline J-test (prob. level) & .79 & .97 & .34 & .86 \\
\hline Auto (1) & .02 & .06 & .13 & .01 \\
(2) & -.38 & -.35 & -.26 & -.39 \\
(3) & -.14 & -.13 & -.09 & -.14 \\
(4) & -.03 & -.02 & -.04 & -.03 \\
\hline
\end{tabular}

Notes: Numbers in parentheses are standard errors.

* indicates significance at the 5 percent level.

${ }^{\dagger}$ indicates significance at the 10 percent level.

$\omega$ is the nonrational share.

$\mathrm{OPH}$ is output per hour, or average labor productivity. 
Figure 1

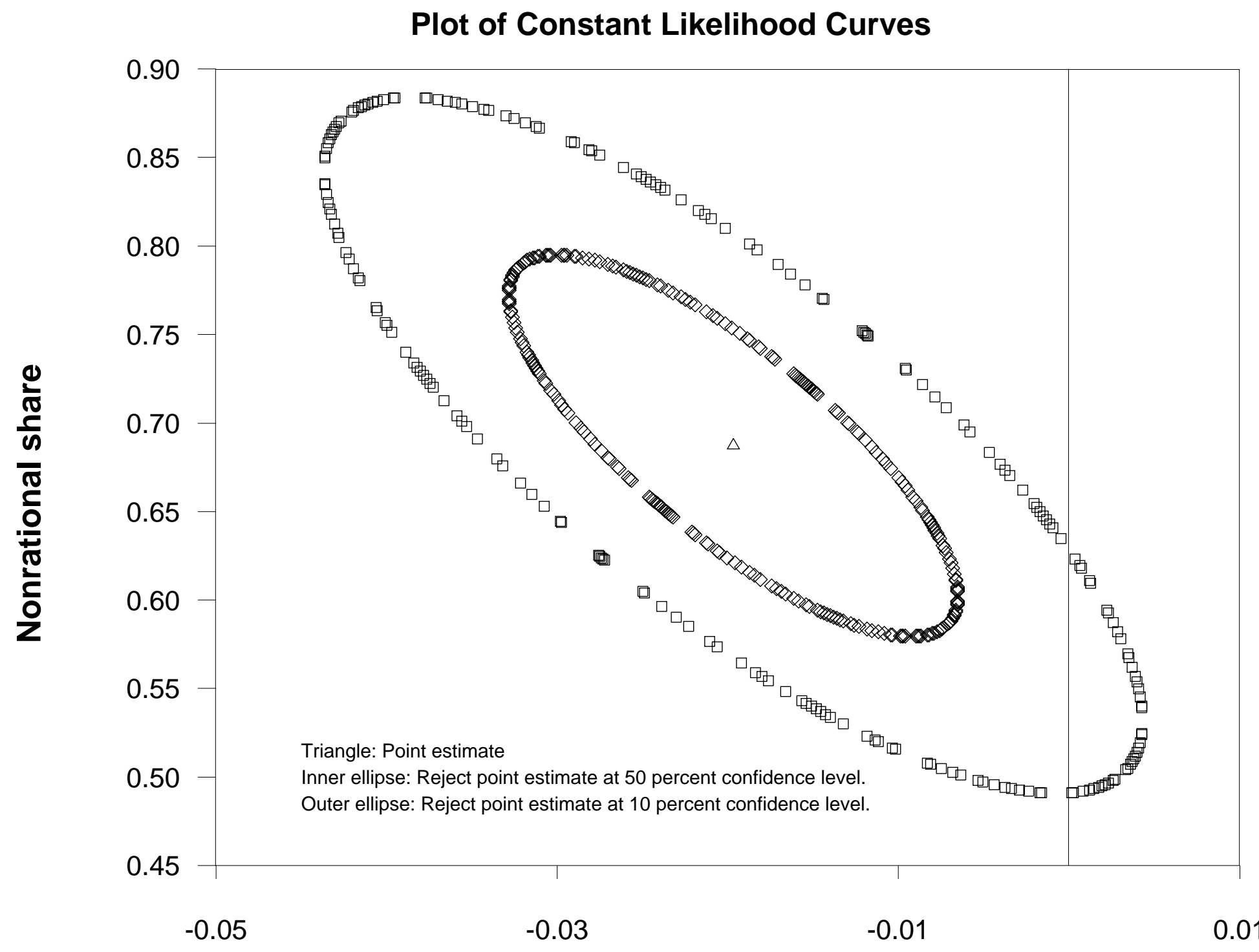

Phillips curve slope 
Figure 2

Plot of Constant Likelihood Curves, Based on Model Allowing for Regime Shift

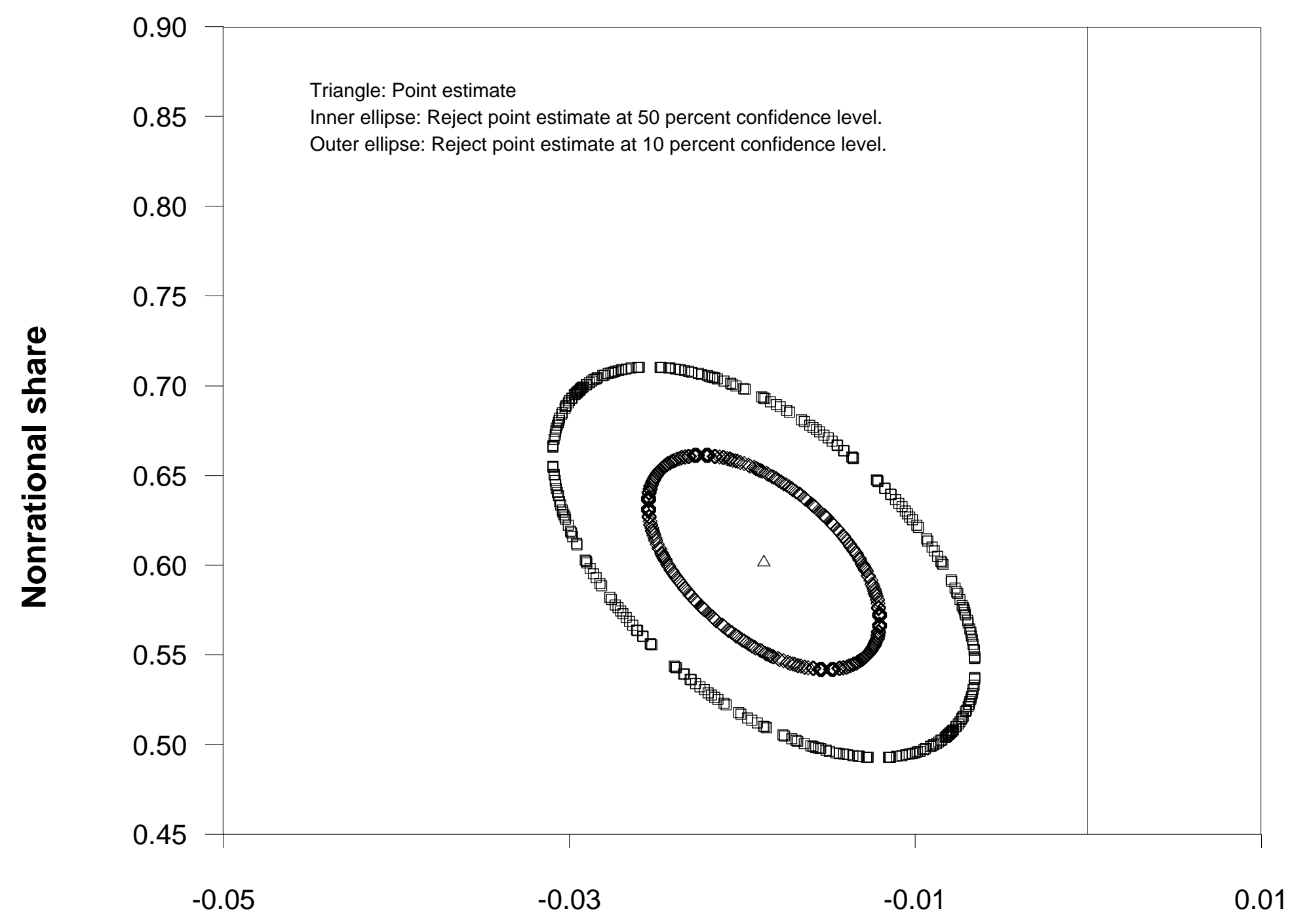

Phillips curve slope 


\section{References}

Ball, Laurence, and David Romer (1990) "Real Rigidities and the Nonneutrality of Money," Review of Economic Studies 57, 183-203.

Brayton, Flint, Andrew Levin, Ralph Tryon, and John C. Williams (1997) "The Evolution of Macro Models at the Federal Reserve Board," Carnegie-Rochester Conference Series on Public Policy 47, 43-81.

Buiter, Willem, and Ian Jewitt (1981) "Staggered Wage Setting with Real Wage Relativities: Variations on a Theme of Taylor," The Manchester School 49, 211-28.

Calvo, Guillermo A. (1983) "Staggered Contracts in a Utility-Maximizing Framework," Journal of Monetary Economics 12, 383-98.

Chadha, Bankim, Paul R. Masson, and Guy Meredith (1992) "Models of Inflation and the Costs of Disinflation," IMF Staff Papers 39, 395-431.

Clarida, Richard, Jordi Gali, and Mark Gertler (1998) "Monetary Policy Rules in Practice: Some International Evidence,” European Economic Review 42, 1033-67.

Dotsey, Michael, Robert G. King, and Alexander L. Wolman (1999) "State-Dependent Pricing and the General Equilibrium Dynamics of Money and Output," Quarterly Journal of Economics 114, 655-90.

Fuhrer, Jeffrey (1997a) "Inflation/Output Variance Trade-offs and Optimal Monetary Policy," Journal of Money, Credit, and Banking 29, 214-34. (1997b) "The (Un)Importance of Forward-Looking Behavior in Price Specifications," Journal of Money, Credit, and Banking 29, 338-50. and George R. Moore (1995) “Inflation Persistence,” Quarterly Journal of Economics $110,127-59$.

Gali, Jordi and Mark Gertler (1999) "Inflation Dynamics: A Structural Econometric Analysis," Journal of Monetary Economics 44, 195-222.

King, Robert G., and Alexander L. Wolman (1999) "What Should the Monetary Authority Do When Prices Are Sticky?" in John B. Taylor, ed., Monetary Policy Rules, University of Chicago Press, 349-404.

Levin, Andrew, Volker Wieland, and John C. Williams (1999) "Robustness of Simple Monetary Policy Rules under Model Uncertainty,” in John B. Taylor, ed., Monetary Policy Rules, University of Chicago Press, 263-318. 
Lucas, Robert E. (1967) “Adjustment Costs and the Theory of Supply,” Journal of Political Economy 75, 321-34.

Roberts, John M. (1992) “Evidence on Price Adjustment Costs in U.S. Manufacturing Industry,” Economic Inquiry 30, 399-417. (1995) "New Keynesian Economics and the Phillips Curve," Journal of Money, Credit, and Banking 27, 975-84. (1997) “Is Inflation Sticky?” Journal of Monetary Economics 39, 173-96. (1998) “Inflation Expectations and the Transmission of Monetary Policy,” Federal Reserve Board FEDS working paper no. 1998-43 (October). , David J. Stockton, and Charles S. Struckmeyer (1994) "Evidence on the Flexibility of Prices," Review of Economics and Statistics 76, 142-50.

Rotemberg, Julio J. (1982) "Sticky Prices in the United States," Journal of Political Economy 60, 1187-1211.

(1987) “The New Keynesian Microfoundations," in Stanley Fischer, ed., NBER Macroeconomics Annual 1987, MIT Press, 69-104. and Michael Woodford (1997) “An Optimization-Based Econometric Framework for the Evaluation of Monetary Policy," in Ben S. Bernanke and Julio J. Rotemberg, eds., NBER Macroeconomics Annual 1997, MIT Press. and (1999) “Interest Rate Rules in an Estimated Sticky Price Model,” in John B. Taylor, ed., Monetary Policy Rules, University of Chicago Press, 57-126.

Rudebusch, Glenn D. (2000) “Assessing Nominal Income Rules for Monetary Policy with Model and Data Uncertainty," working paper, $\underline{w w w . s f . f r b . o r g / e c o n r s r c h / e c o n o m i s t s / ~}$ grudebusch.html

Sbordone, Argia M. (1998) "Prices and Unit Labor Costs: A New Test of Price Stickiness," working paper, Rutgers University (October).

Taylor, John B., (1999), ed., Monetary Policy Rules, University of Chicago Press. 